\title{
FOREST PATCH CONSERVATION INDICATORS
}

\author{
Costa, T. C. C. ${ }^{1 *}$-FIDALGO, E. C. C. ${ }^{2}-$ RAID, M. A. M. ${ }^{3}-$ RibeirO, J. L. ${ }^{4}-$ VianA, J. H. M. ${ }^{1}-$ \\ FERREIRA, F. N. ${ }^{5}-$ MIRANDA, G. A. ${ }^{5}-$ MARRIEL, I. E. $^{1}-$ PAIVA, C. A. O. ${ }^{1}$ \\ $1^{*}$ Embrapa Milho e Sorgo, Rod. MG 424 Km 45, 35701-970, Sete Lagoas, Brazil \\ (phone: +55-31-3027-1159; fax: +55-31-3027-1188)
}

${ }^{2}$ Embrapa Solos, Rua Jardim Botânico, 1.024, B. Jardim Botânico, 22460-000, Rio de Janeiro, RJ, Brazil

${ }^{3}$ Universidade Federal de Minas Gerais, SMARH, Av. Antônio Carlos, 6627, BL01, SL 4619, 31270-901, Belo Horizonte, MG, Brazil

${ }^{4}$ Universidade Federal de São João del - Rei, Campus Sete Lagoas, Rod. MG $424 \mathrm{Km}$ 47, 35701-970, Sete Lagoas, MG, Brazil

${ }^{5}$ Centro Universitário de Sete Lagoas, Av. Marechal Castelo Branco, 2765, B. Santo Antônio, 35701-242, Sete Lagoas, MG, Brazil

*Corresponding author

e-mail: thomaz.costa@embrapa.br

(Received $27^{\text {th }}$ Jan 2016; accepted $30^{\text {th }}$ May 2016)

\begin{abstract}
This work presents indicators to assess the conservation status of forest patches in fragmented landscapes. However, how can we evaluate the conservation status of forest patches in order to compare it to a hypothetical situation of well-preserved vegetation without human disturbance? It is possible to measure some ecological processes, like nutrient cycling, canopy, edaphic, topographic and hydrological parameters, as well as landscape attributes, and associate them to conservation status. When the attributes of original well-preserved forest are unknown because they are seldom found, it is possible to compare patches by assessing the variability of their attributes. To this end, parameters related to canopy, soil, topography and landscape were analyzed to establish indicators and their integrated analysis was developed to assess the conservation status of forest patches and identify possible causes of shortcomings or obstacles to reach the conservation status. The study area is located in a Semidecidual Forest region, in Brazil. The methodology was developed considering plots distributed in sites within forest patches. The results allowed the identification of patches in different conditions of conservation and provided information of the factors that contribute to this status, in order to help guide and select the most appropriate measures to mitigate degradation and identify forest conservation strategies.
\end{abstract}

Keywords: vegetation assessement, decision support, forest sites, ecosystem parameters

\section{Introduction}

Many strata of society have sought valuation, restoration and maintenance of forests and have set them as goals in political agendas. Protection strategies converge as lines of preservation, conservation, ecosystem restoration and, most recently, ecosystem services, such as nutrient flows into neighboring areas, capture and sequestration of carbon by biomass and soil, water storage and purification, organic waste decomposition and detoxification, flood and drought mitigation, soil fertility renewal, food production, biological pest control and conservation of pollinators and seed dispersers (Zhang and Swintow, 2009; Altieri, 1999).

The maintenance of forest ecosystems depends on physical factors which influence the colonization, permanence and dynamics of potential plant species, and also 
influence the biological rhythms of the plants in the biomes (Machado and Lopes, 2002; Araujo and Ferraz, 2003). Rainfall, as well as geographical location, topography configuration and soil conditions (fertility and organic matter, soil depth, among others) have a link with the distribution of species and biomass production (Sampaio, 2003). The factors that affect forests are human activities, which reduce biomass and floristic composition, changing vegetation structure and dividing forest ecosystems into mosaic forms (Oliveira, et al., 2000).

How can a forest patch be evaluated comparing it to its hypothetical full potential, in which it would have attributes with maximum values, without human interference or environmental constraints? At a forest ecosystem, assigning reference values for the productivity of sites is not possible because the combination of environmental constraints and ecological requirements of species result in the variability of the productivity in each site, even considering the cases they are almost undisturbed. Thus, it is not feasible to select a supposed preserved or a less changed forest patch and use it to know the succession stage of other patches. But the comparison among relative conditions of the sites seems a good way to understand the conditions of conservation of patches.

Then, the alternative to compare forest patches would be to measure some ecological processes, such as nutrient cycling, and landscape and canopy parameters (dendrometry, biophysics, diversity), as well as edaphic, topographical and hydrological processes. The variability of these parameters can be used to produce relative valuation of the patches of a certain type in the same biome on a local scale, considering a constant climate. This information can be used to assess the intensity of patch degradation.

These parameters can be considered indicators, with the ability to summarize, to focus and to condense the complexity of the dynamic environment to a manageable amount of meaningful information (Godfrey and Todd, 2001; apud Singh et al., 2009).

Many organizations are turning to a criteria and indicators $(\mathrm{C} \& \mathrm{I})$ approach to assess and plan for forest sustainability. Under this approach, criteria define broad categories of sustainability, and indicators are specific measurements (quantitative or qualitative) within each category. A framework of criteria and indicators is a valuable tool when used for assessments, planning, issue management, inventory and monitoring, and communicating with others (USDA, 2003).

A set of indicators has to be wisely selected (Niemeijer and De Groot, 2008; Van Oudenhoven et al., 2012; apud Kandziora et al., 2013), based on specific management purposes, with an integrating, synoptical value, which (in the best case scenario) shows the difference between existing states and aspired target situations. Indicators are also comprehended as depictions of qualities, quantities, states or interactions that are not directly accessible (Kandziora et al., 2013).

For especific forest case a approach of indicators in large scale was proposed by Noss (1999). But when we think on evaluate the forest structure, biodiversity, associated with site quality, it is necessary increase detail to measure variables in the forest, that is, big scale.

The classification of vegetation in phytogeographic systems is a way to associate the knowledge of flora and vegetation types to climate and geomorphological conditions on a large-scale, in order to group similar ecosystems together (IBGE, 2012; Oliveira et al., 2010). Otherwise, on a local scale it is possible to indirectly assess the conservation status of these typologies by analyzing environmental and anthropogenic parameters (Costa, et al., 2009a; Costa et al., 2009b). 
In forest inventories, the main dendrometric parameters used as aboveground biomass and forest development indicators are: basal area (B), density of individuals (D) and average height (h). The botanical identification of species makes it possible to obtain floristic diversity indexes such as the Shannon-Weaver $\left(\mathrm{H}^{\prime}\right)$ and the Simpson's Dominance (C). Among the biophysical indicators, there is the leaf area index (LAI), related to plants' physiological processes, such as photosynthesis, respiration and transpiration to produce biomass.

Nutrient cycling is one of the most studied ecological processes in forest ecosystems controlled by litter (Costa et al., 2014; Valenti et al., 2008; Moreira and Siqueira, 2002; Paula and Lemos Filho, 2001; Barichello et al., 2000; Poggiani and Schumacher, 2000; Brun et al., 1999; Feger and Raspe, 1998; Cunha, 1997). One of the purposes of measuring litter deposition is to estimate the efficiency of natural ecosystems to provide soil with the nutrients needed for its maintenance (Silva et al., 2009). Two parameters used to evaluate nutrient cycling are litterfall, decomposition rate and leaf nutrients.

Regarding the edaphic component, we can mention fertility and grain size parameters and decomposition activators, which are organisms of the meso-fauna and micro-fauna. A part of the decomposition process can be measured by enzyme activity, such as urease, arginase, acid phosphatase, alkaline phosphatase, hydrolases in general and basal soil respiration (Silveira and Freitas, 2007; Marriel, 2008; Aquino and Assis, 2005). In theory there is a relationship between the quantity of the fallen leaves of the canopy, the decomposition rate and the microbial activity, due to the lack of litter accumulation on forest soils.

Topographical conditions, such as altitude, slope, aspect and slope curvature determine microclimates, storage, runoff and the amount of incident solar radiation. Regarding the hydrological component, parameters such as distance and elevation of the sites in relation to water bodies are related to water availability.

Patch size, shape and isolation are important to characterize landscape structure (Turner, 1989; Sih and Luikart, 2000; Nascimento and Laurence, 2006; Mcgarigal, 2011). All parameters described at site or landscape scale are related to the conservation and the succession stage.

All these parameters are affected by ecosystem heterogeneity which refers to inconsistencies of the spatial and temporal distribution of abiotic and other habitat parameters, indicated, for example, by landscape metrics related to soil conditions, geomorphologic items, microclimate or hydrological characteristics (Burkhard et al., 2011 and Eea, 2007 apud Kandziora et al., 2013).

Thus, considering the hypothesis that forest patches of the same biome, in better conservation conditions, show the best results for the parameters related to canopy, soil and landscape characteristics, the analysis of indicators associated to these characteristics can demonstrate the conservation status of forest patches, as well as the source of restrictions to its development. Also, considering the influence of local topographic variations on the type of vegetation, the inclusion of an indicator comprising topographic parameters completes this analysis.

Based on this premise, this study aims to analyze the behavior of various parameters related to canopy, soil, topography and landscape to establish indicators and their integrated analysis to assess the conservation status of forest patches and identify possible causes of shortcomings or obstacles to its full development. 


\section{Material and Methods}

The study area is the experimental farm of Embrapa Milho e Sorgo, located in the city of Sete Lagoas, Minas Gerais, Brazil in a region with the following vegetation types: Savannah Park, Grassy-Woody Savannah, Savannah Tree, Savannah Woodland, Lowland and Semideciduous Forest and Evergreen Seasonal Forest (IBGE, 1988).

The Köppen climate classification is Cwa (Peel et al., 2007), indicating Savannah climate with dry winters and rainy summers. The average annual temperature is $21.1^{\circ} \mathrm{C}$ $\pm 6.0^{\circ} \mathrm{C}$. The average annual rainfall is $1,384 \mathrm{~mm}$ and the average annual potential evapotranspiration is approximately $1,444 \mathrm{~mm}$ (Gomide et al., 2006).

The region is on the geological contact between the granites of the crystalline basement (Belo Horizonte Supergroup), and sedimentary rocks of the Bambuí Group; the latter is the dominant lithology of the study area. The regional topography consists of gently rolling hills.

Eight patches of forest physiognomy were selected for this study, characterized by the absence of grass in the understory layer, the presence of straight tree trunks, high canopy, non-coriaceous leaves, not in the early stages of the ecological succession, and at least 50 years old of recovering from pasture.

Twelve sites were selected in these patches (Fig. 1) and 27 plots, 20 x 20 meters, were marked in 100 meters from the edge of the patches. The number of sites and plots is proportional to the size of the patches. There are: Patch 1: three sites $(11,12$ and 13) with two plots each; Patch 2: one site (21) with three plots; Patch 3: one site (31) with one plot; Patch 4: one site (41) with three plots; Patch 5: two sites (51 and 52) with two plots each; Patch 6: one site (61) with three plots; Patch 7: one site (71) with three plots; and Patch 8: two sites (81 and 82) with two plots each.

The phytosociological inventory was carried out measuring trees with diameters over $5 \mathrm{~cm}$ at breast height $(\mathrm{DBH})$, and the botanical collection of material was sent to the PAMG-EPAMIG Herbarium of Minas Gerais, identified by the APGIII System (APG, 2009). The variables obtained by site were: density (D) ind. $\mathrm{m}^{-2}$; basal area (B) $\mathrm{m}^{2} \cdot \mathrm{ha}^{-1}$; average canopy height $(\mathrm{h}) \mathrm{m}$; Shannon diversity index $\left(\mathrm{H}^{\prime}\right)$ and Simpson dominance index (C). The sites were then classified by forest type using the species ecology information (IBGE, 2012).

In order to measure the leaf area index (LAI) we used the LAI 2200 (LI-COR, 2011). The methodological procedure is described by Costa et al. (2014). The LAI was measured per plot, then the average annual value per site was calculated, LAImd_anual ( $\mathrm{m}^{2}$ of leaves. $\mathrm{m}^{-2}$ of land).

The soils at each site were classified with profiles until 1.6 meters deep. At the bottom of the profiles, boreholes were made to verify uniformity of the material. The thicknesses of each Horizon was measured, and fertility and grain size parameters were obtained accordingly to the brazilian official soil methods (DONAGEMA et al., 2011). As the first contribution of the literfall to soil is on A thickness, we used the depth of Horizon A, its fertility and its grain size parameters for the comparisons. And we used the agricultural and planted forest references for the interpretation of the soil fertility indicators due to the lack of detailed knowledge concerning the real nutritional needs of these native species. 


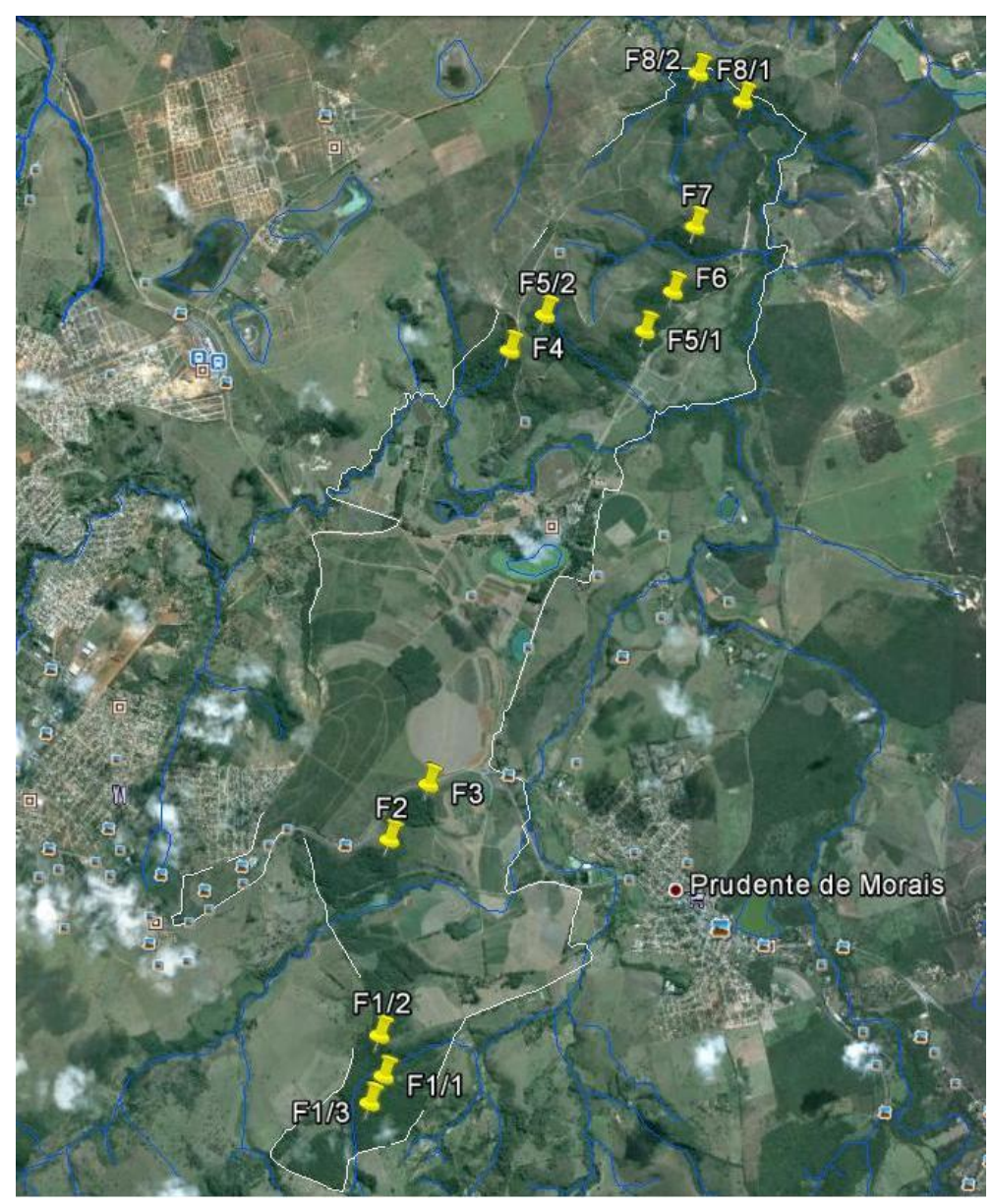

Figure 1. Location of the sites in each patch (F1/1 to F8/2) on the experimental farm of Embrapa, Sete Lagoas, Minas Gerais, Brazil. Source of image: Google Earth

In order to characterize nutrient cycling, we evaluated the deposition of leaf litter (leaves), the dry weight of leaves $\mathrm{g}^{-\mathrm{m}^{-2}}$.year ${ }^{-1}$ (psfhanual) (described by Costa et al., 2014), the leaf decomposition rate (k) and microbial activity indicators: arginase (ARG, in $\mu \mathrm{g} \mathrm{NH} 4 . \mathrm{g}^{-1} \cdot \mathrm{h}^{-1}$ ), fluorescein diacetate hydrolysis (FDA in $\mu \mathrm{g} \cdot \mathrm{g}^{-1} \cdot \mathrm{h}^{-1}$ ), acid phosphatase and alkaline phosphatase (FOSFacid and FOSFbas, respectively, both in $\left.\mu \mathrm{g} \cdot \mathrm{g}^{-1} \cdot \mathrm{h}^{-1}\right)$, urease (UREAS in $\left.\mu \mathrm{g} \cdot \mathrm{g}^{-1} \cdot \mathrm{h}^{-1}\right)$, basal respiration $\left(\mathrm{CO}_{2}\right.$, in $\left.\mathrm{ml} \cdot \mathrm{kg}^{-1} \cdot \mathrm{h}^{-1}\right)$.

To obtain the litter decomposition rate, samples of $10 \mathrm{~g}$ were introduced into litterbags which provide $75 \%$ shade, with a mesh of $1 \mathrm{~mm} \times 5 \mathrm{~mm}, 25 \times 25 \mathrm{~cm}$ total size. The litterbags were distributed at 11 sites on Aug. 11, 2011, 12 bags at each site (site 13, code for Path 1 and plot 3, was not sampled, because it is similar to site 11, code for path 1 and plot 1). Samples were collected on Feb. 15, 2012, May 15, Sep.14, and Dec.18 of the same year. Each collection had three repetitions and the collected material underwent a screening process to remove soil residues, dead animal remains and other impurities. After the cleaning, the material was placed in a kiln at $65^{\circ} \mathrm{C}$ for 48 hours. After weight was stabilized, the material was weighed. To estimate the litter decomposition rate we used the simplified model $x=b^{*} e^{-k t}$ (Manzoni et al., 2012), adjusted for each site, in which $\mathrm{x}$ is the dry weight of remaining litter at time $\mathrm{t}$; and $-\mathrm{k}$ is the rate of litter decomposition. The parameters evaluated were mean values and confidence intervals of $\mathrm{k}$ and $\mathrm{b}$. 
Microbiological analyses were performed by collecting four soil samples at each site at $0-20 \mathrm{~cm}$ depth. The samples were stored and kept in the refrigerator at temperatures between 7 and $10^{\circ} \mathrm{C}$. These samples were obtained in the rainy season, in which there is higher biological activity. The methods applied to quantify the parameters of microbial activity are described by the authors mentioned: urease (Gerber and Kandeler, 1988), arginase (Alef and Keiner, 1986), acid and alkaline phosphatase (Tabatai and Bremmer, 1969), FDA (Adam and Duncan, 2001), and basal respiration (Silva et al., 2007).

The topography parameters were obtained from a digital elevation model with fivemeter resolution, generated by the map of the farm with two-meter contour lines. The parameters of altitude (Alt), slope, slope orientation (aspect), curvature profile (crprof) and curvature plane (crplan) were generated after corrections to avoid spurious depressions and other inconsistencies in the model. The values per site and patch were then obtained using zonal statistic tools.

Considering that the regional climate has six dry months, the environments with favorable topography for water accumulation are usually colonized by plant communities of forest phytophysiognomies. The concavity and slope parameters were used as topography indicators of nutrient and water accumulation, which could be observed on concave surfaces.

Information on the hydrological influence obtained through water balance per site and hydrogeological studies have very high costs. In this study, the groundwater supply parameters used were the distance (distwat) and the altitude difference (altwat) between the site and the nearest water bodies - perennial or intermittent streams.

The landscape parameters were obtained using land use/land cover data on the experimental farm and its surroundings, delimited via visual interpretation of images available on Google Earth from August 22, 2011 to April 16, 2013. The classes delimited within the farm were: lake, lowland, railway, highway, urban (built area), bare soil, experimental field, pasture, forest plantation, Savannah Park, Grassy-Woody Savannah, Savannah Tree, Savannah Woodland, Semideciduous Forest and Evergreen Seasonal Forest. Outside the farm borders, only the natural vegetation was mapped and classified as Semideciduous Forest or Savannah.

The parameters that represent the extent and the shapes of patches of the sites as well as their position in relation to other patches in the landscape were obtained using the Fragstats program (McGarigal, 2011). To do so, the land use/land cover map was rasterized at the same resolution as the digital elevation model, and then the parameters, whose description can be found in McGarigal (2011), were calculated: Area (Area), Circumscribed Circle (CIRCLE), Contiguity Index (CONTIG), Euclidean Distance of Nearest Neighbor (ENN) and Proximity Index (PROX).

Whereas the use in patch surroundings affects the conditions of such patches (Werneck., 2001; Tabarelli et al, 2008), we calculated the percentage of the patch perimeters bordering natural vegetation (limAreNat), i.e., the land use/land cover that does not represent a negative impact on patch conservation.

We did not joined these data in one integrated multivariate analysis, for example Multiple Factor Analysis, due to the difficulty to extract relevant informations after the number of transformations and because of the possible loss of variation of the original data. And we noticed that some variables did not explain the expected relationships among parameters because of the complex interation of the factors that drive forest quality. Then, to compare the obtained parameters in the different patches and sites, we used Principal Component Analysis (PCA) applied by group of variable to assess the 
magnitude of the correlation and the direction of each variable.To analyze the sites, we worked with parameter groups:

- canopy - D, B, h, H', C and LAI;

- soil - $\mathrm{pH}$ in water $\left(\mathrm{pH}_{\mathrm{H} 2 \mathrm{O}}\right)$ with $\mathrm{pHmeter}$ (soil/water relation 1:2.5), phosphorus $(\mathrm{P})$ extracted by the Mehlich 1 solution, potassium (K) by $\mathrm{HCl} \mathrm{0,05} \mathrm{M} \mathrm{solution,} \mathrm{calcium}$ (Ca) and magnesium ( $\mathrm{Mg})$ by the $\mathrm{KCl} 1 \mathrm{M}$ extrator method and ICP-OES determination, aluminum ( $\mathrm{Al}$ ) by the $\mathrm{KCl} 1 \mathrm{M}$ extrator and titration method, potential acidity $(\mathrm{H}+\mathrm{Al})$, sum of bases (SB), potential cation exchange capacity $(\mathrm{CTC}(\mathrm{T}))$ by the $\mathrm{Ca}$ acetate at $\mathrm{pH} 7$ extrator method, effective cation exchange capacity $(\mathrm{CTC}(\mathrm{t}))$ by the $\mathrm{KCl} 1 \mathrm{M}$ extrator method, organic matter $(\mathrm{OM})$ by dry combustion method with an elemental analyzer, percentage of base saturation $(\mathrm{V})$, percentage of aluminum saturation $(\mathrm{m})$, zinc $(\mathrm{Zn})$, iron $(\mathrm{Fe})$, manganese $(\mathrm{Mn})$, copper $(\mathrm{Cu})$, the last four extracted by the Mehlich 1 solution, gravel, fine soil, coarse sand, fine sand, silt, clay (by sieving and the pipete method) and horizon depth (Prof);

- nutrient cycling and microbial activity - leaves, k, ARG, FDA, FOSFacid, FOSFbas, UREAS and $\mathrm{CO}_{2}$; and

- topograph and water proximity - crprof, crplan, slope, aspect, distwat and altwat.

Regarding the patches, we worked with the groups of parameters related to the landscape: Area, CIRCLE, CONTIG, ENN, PROX and LimAreNat.

After this exploratory analysis, knowing the a priori relevance relationship of each parameter and the conditions of the forest patches, we obtained the evaluation indicators that contained parameters of different types, units and scales and used simple support decision methodology (Eastman et al., 1995). As we did not judge which parameter is more important than others to conservation, we did not use weights, we considered the simple average of the parameters.

Due to this diversity, it was necessary to standardize the response of the parameters and establish relevant relationships to the goal (Eastman et al., 1995; Mello Filho et al., 2007). The standardization was performed on a 0-1 scale, and the relevance relationships adopted were linear and fuzzy trapezoidal with thresholds obtained from the literature or from the data series. To promote conservation ( $\mathrm{S}$ goal), the conservation indicator was the average of the standardized parameters, $\mathrm{S}=$ mean $\left(\mathrm{x}_{\mathrm{i}}\right)$ considering that they have the same importance.

\section{Results and Discussion}

\section{Canopy}

Regarding canopy, the magnitude and direction of the parameters in Component 1 of the PCA (Fig. 2) show a cluster of sites 31, 81, 82, 41, 51 and 52 in relation to aerial biomass, parameters B, D, h, LAI; and in relation to diversity, parameters $\mathrm{H}^{\prime}$ and $\mathrm{C}$. The undesirable variable to conservation, $\mathrm{C}$, is on the left, along with sites $11,12,13$ and 71. Sites 21 and 61 showed heterogeneity in plots 213 and 613, because these plots have a more developed understore layer and higher density of individuals when compared to the other plots of the respective sites. Plot 411 is not close to the other plots of Site 41 due to unfavorable topographical conditions, which reflected negatively on canopy parameters. 


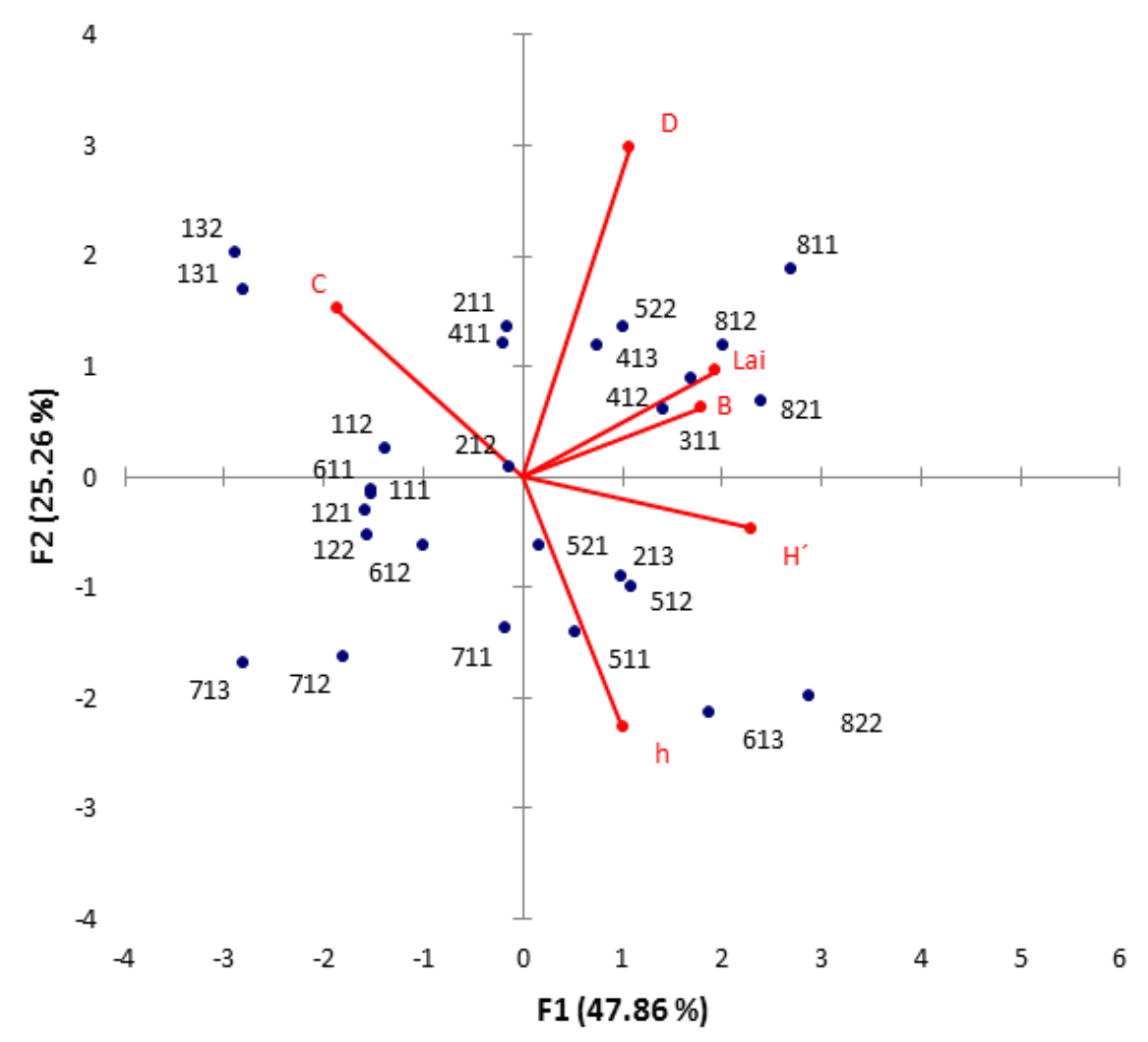

Figure 2. Joint dispersion of canopy parameters and plots in the sites for Components 1 and 2 (F1 and F2) of the PCA

\section{Soils}

In the evaluation of fertility, depth and grain size (Fig. 3), we found that the retention of cations $(\mathrm{CTC}(\mathrm{t}), \mathrm{CTC}(\mathrm{T}))$ is more related to organic matter content (MO) than to clay activity, because these soils, highly weathered, have low clay activity. Figure 3 shows the vector of the proportion of clay in the direction approximately orthogonal to the main fertility parameters, including the vector of organic matter. This is evidence that the fertility of Horizon A is mainly supplied by nutrient cycling processes, not by the source material which forms the soils of the study area.

This indicates that the biotic ecosystem components affect the spatial and temporal patterns of the abiotic habitat components of ecosystems, which can be indicated by measuring ecosystem heterogeneity (Müller, 2005 apud Kandziora et al., 2013).

Comparing canopy parameters and those of fertility (Fig. 4), we found that the aerial biomass and diversity do not correlate to the fertility levels of Horizon A at the sites, indicating the existence of other factors which affect structure and floristic diversity. Sites 11, 13 and 71 have higher fertility levels in Horizon A, although their canopy parameters indicate an unfavorable condition for conservation. Sites 11 and 13, may have received fertilization for a long time, as there are records that this area has been used for pasture. Due to its favorable topographic conditions, it may also have been previously cultivated. 


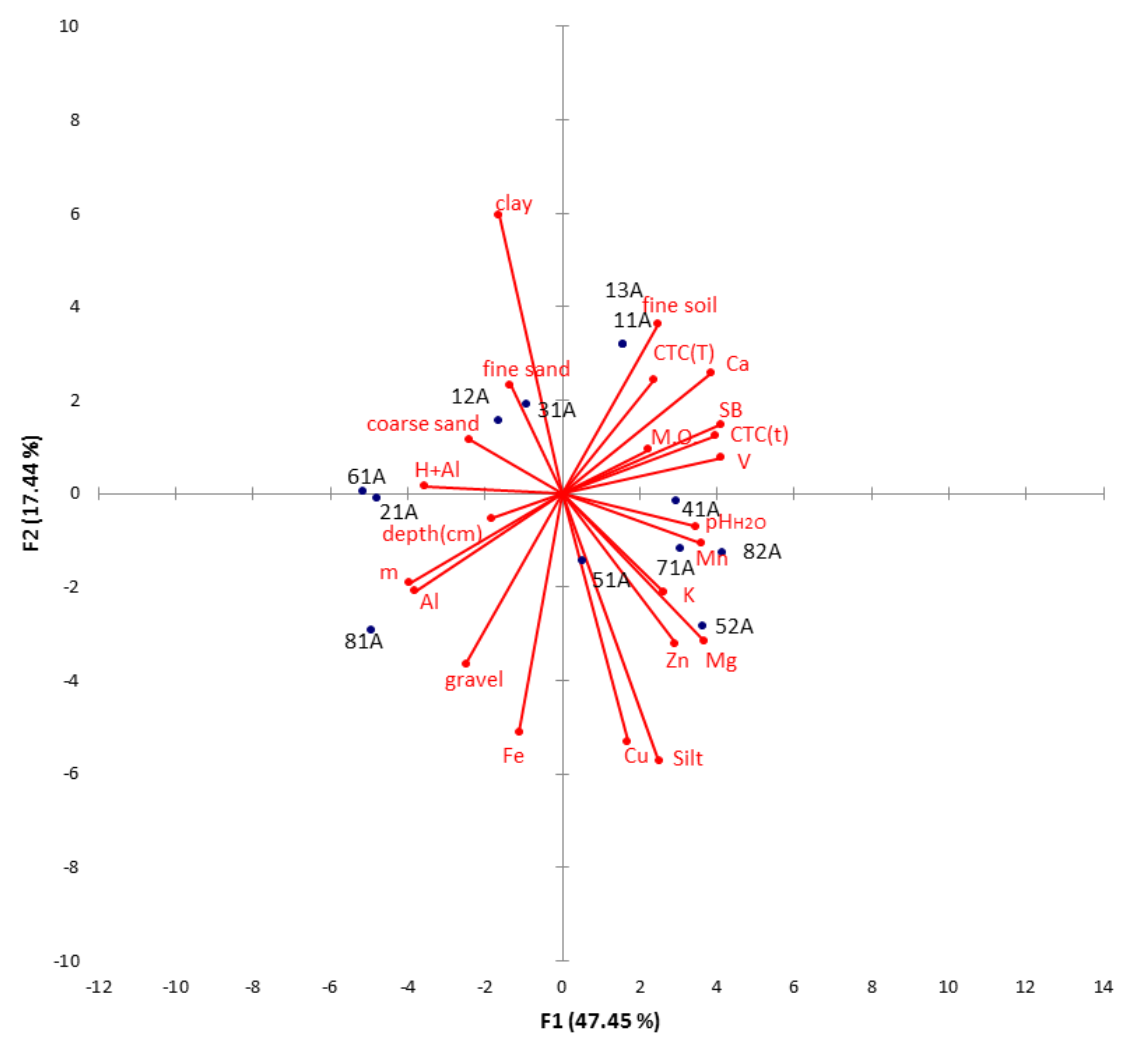

Figure 3. Joint dispersion of particle size and fertility parameters in Horizon A and sites for Components 1 and 2 (F1 and F2) of the PCA

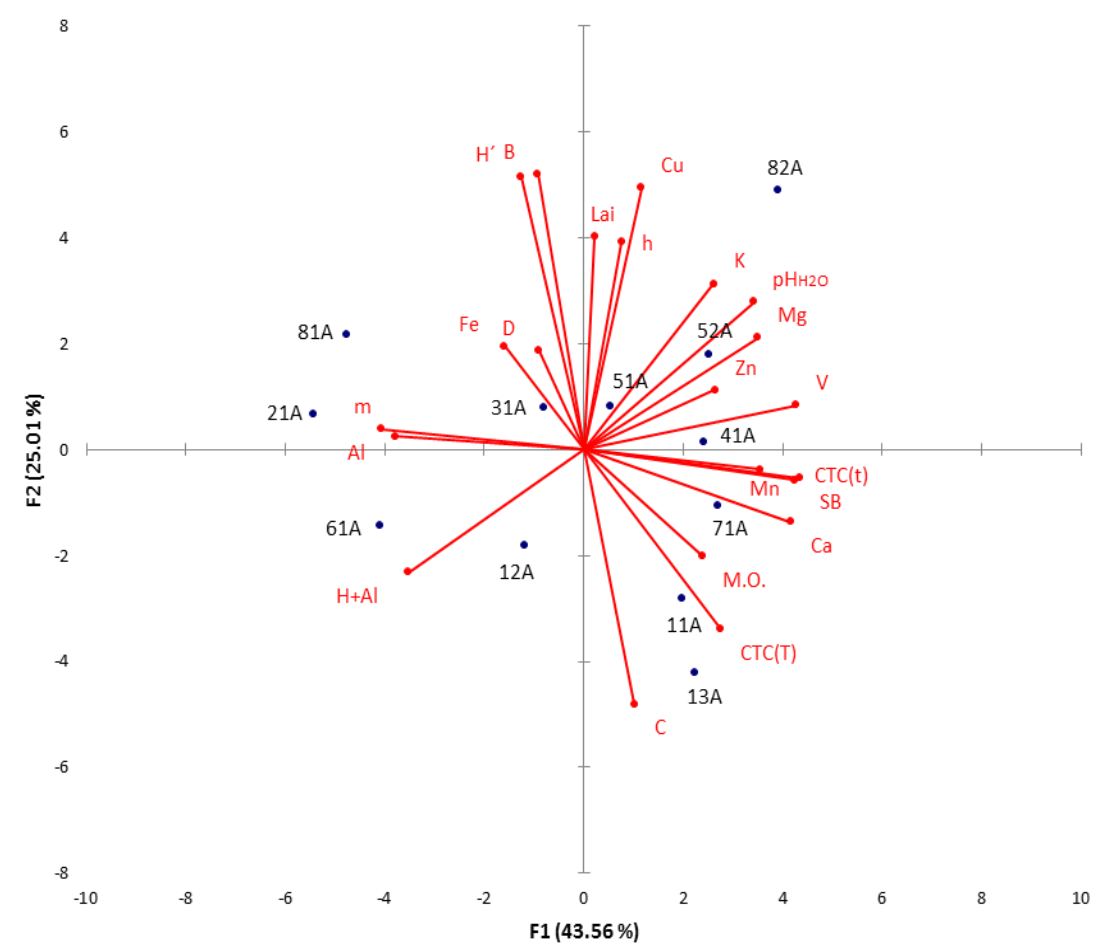

Figure 4. Joint dispersion of canopy (average of plots) and fertility parameters in Horizon A and sites for Components 1 and 2 (F1 and F2) of the PCA 
The sites 21 (F 2/1), 61 (F 6/1) and 81 (F 8/1) have less favorable fertility characteristics. The site 21 (F 2/1) is on a Typic Haplustox (USDA, 1999) (weathered soil with low cation exchange capacity), site 61 (F 6/1) is on Humic Haplustox and site 81 (F 8/1) is on Humic Haplustox (soils with low base saturation). The vegetation in Site 21 is a transition from Semideciduous Forest to Savannah - common in weathered soils with surface acidity; Site 61 is Semideciduous Forest and Site 81 is Evergreen Seasonal Forest. One factor that differentiates Sites 61 and 81 is the presence of groundwater in most favorable conditions in Site 81. It is likely that fertility indicators and groundwater are compensations, as observed at Sites 31 (F 3/1) and 81, which present low fertility, but good water supply, which may have led to a greater structure and diversity of the vegetation in those sites.

\section{Nutrient cycling and microbial activity}

We did not find logical correlations in the vector positions when nutrient cycling parameters were evaluated (Fig. 5). We expected that the amount of annual deposition of leaf litter (leaves) would correlate positively with the leaf decomposition rate (k) and microbial activity parameters (ARG, UREAS, FDA FOSFacid, FOSFbas, $\mathrm{CO}_{2}$ ), because microbial activity is a component in mineralization of organic matter. We expected all these vectors in the PCA to be oriented to sites with higher biomass, diversity and fertility.

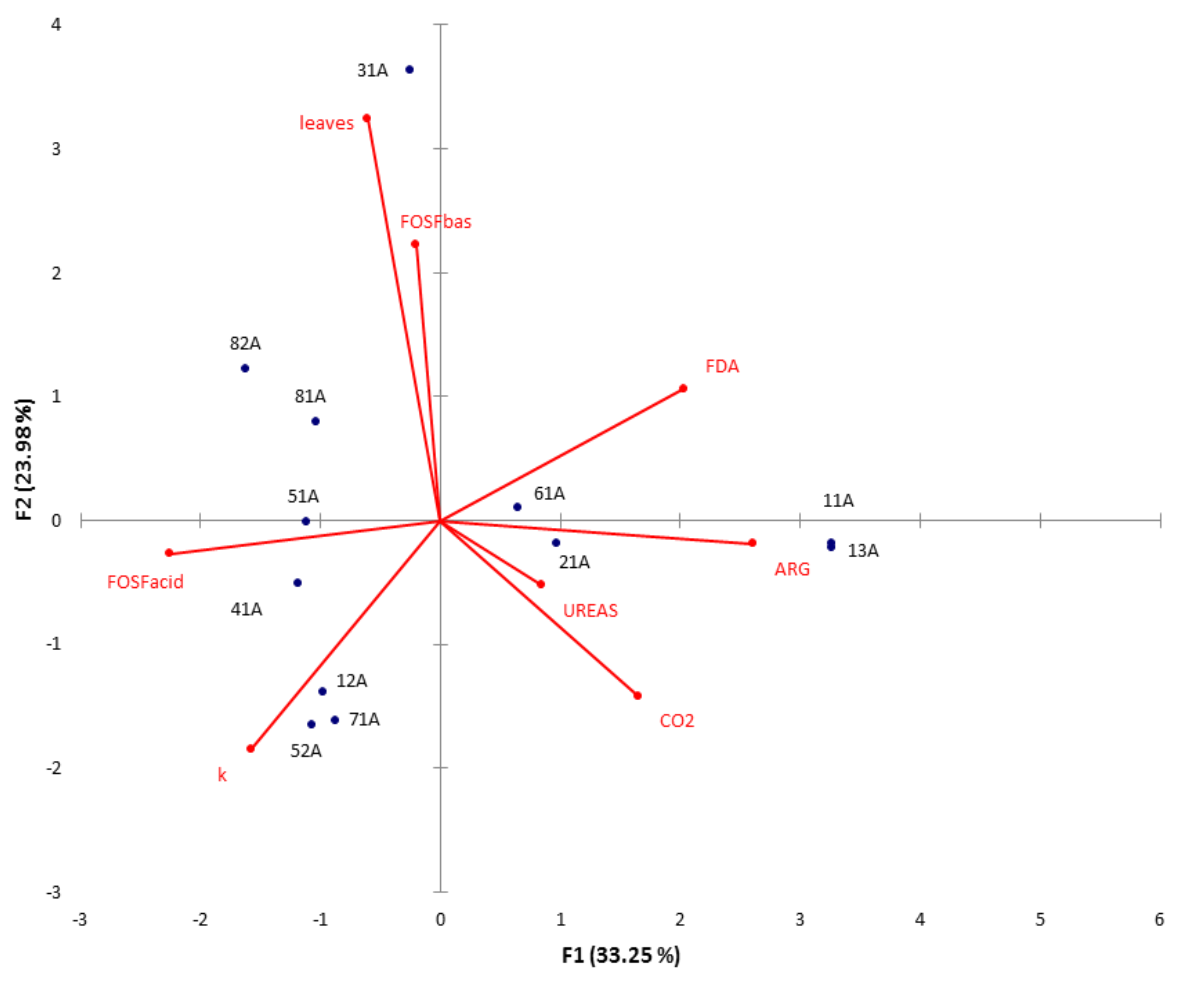

Figure 5. Joint dispersion of cycling parameters and sites for Components 1 and 2 (F1 and F2) of the PCA

The mismatch may be due to low sensitivity of the method to detect differences in the speed of leaf mineralization. Figure 6 shows the leaf decomposition rate (k) 
for each site. We observed that, although rates vary from -0.002 to -0.005 , their dispersion is high and the statistical difference only appears between Sites 81 and 52. The low sensitivity to detect differences in forest ecosystems is due primarily to the similarity between environments, although Sites 11, 12, 13 and 21 are secondary forests at an earlier stage. By using this method, Hayashi (2006) could detect higher annual litter production and higher decomposition rates in primary forests compared to regenerated forests. The accuracy of the procedure also may have affected the results. The material in the litterbags taken in each analysis did not return. Other samples were taken for analysis in the following period. Differences in the decomposition intensity occur because there are variations of fungi and bacteria colonies in the soil. And, finally, the longer the material remains on the ground, the harder it is to identify what leaves are, adding more uncertainty to the outcome. Therefore, the decomposition rate did not show good sensitivity to detect differences between forest ecosystems.

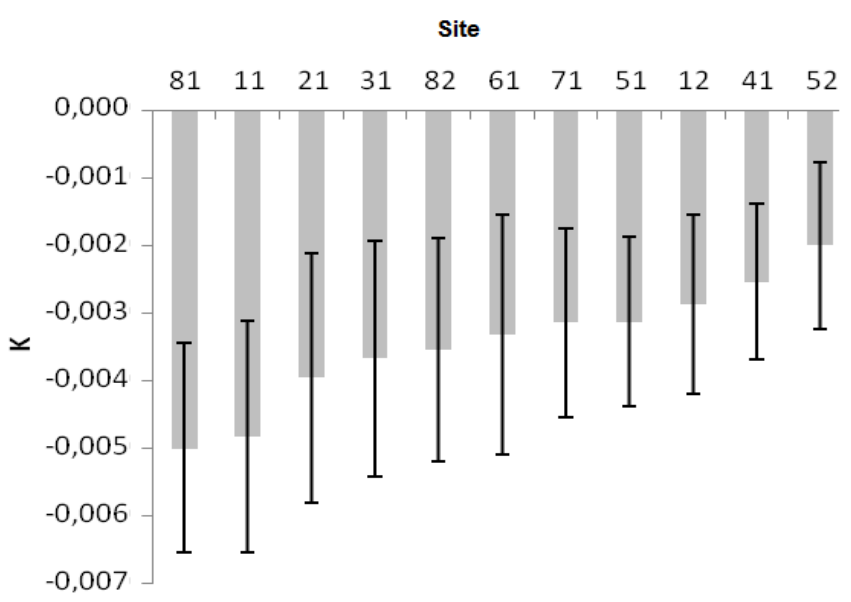

Figure 6. Leaf decomposition rate ( $k$ ) and its lower and upper limits at 95\% confidence interval

Regarding microbial activity, Figures 7, 8 and 9 show the mean values and standard deviation for the ARG, UREAS, FDA, FOSFacid, FOSFbas and $\mathrm{CO}_{2}$ parameters. Analyses of variance, considering treatments (sites) with four replicates per parameter, did not detect significant differences in the levels of UREAS, FDA, FOSFacid and $\mathrm{CO}_{2}$. For ARG, the Scott - Knott means test detected differences between Sites 11/13 and others.

Microbial activity when comparing the different sites showed similarities. Regarding ARG and FOSbas parameters, there were no reasons for ARG to be an outlier at Sites 11/13, nor for the statistically equal results of FOSFbas at Sites 82, 61 and 51, which are different from the other sites.

We could not confirm the hypothesis, with use of this method that higher leaf deposition, nutrient content and microbial activity would lead to higher decomposition rate and soil fertility in Horizon A. 


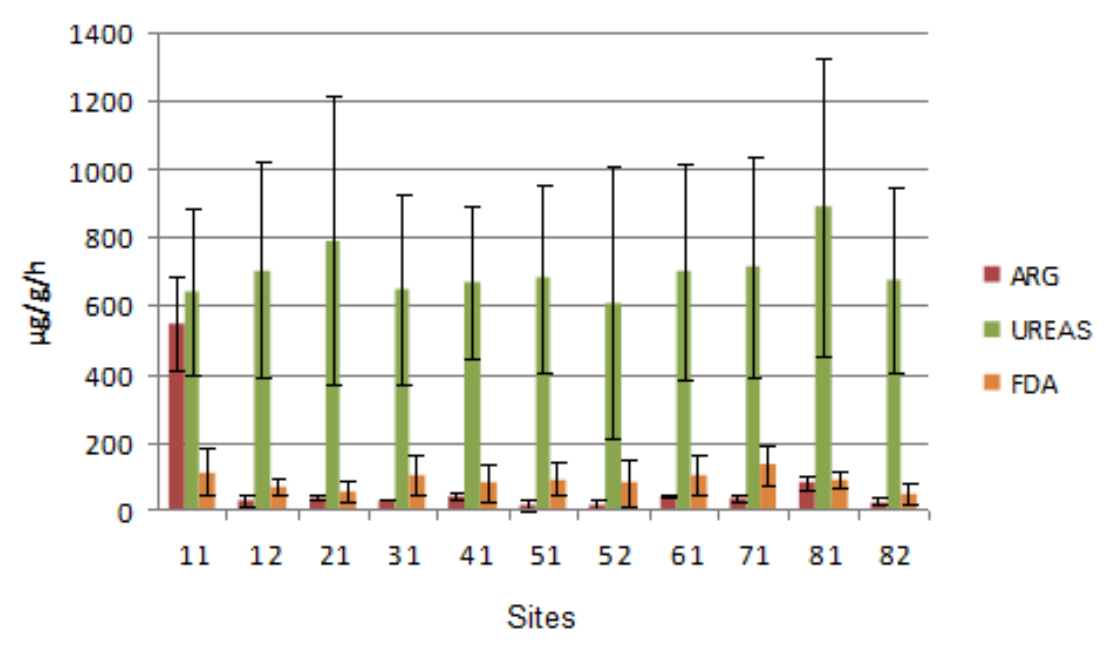

Figure 7. Arginase activity, ARG ( $\mu \mathrm{g} N H 4 / g / h)$; urease, UREAS $(\mu \mathrm{g} / \mathrm{g} / \mathrm{h})$ and hydrolysis of fluorescein diacetate; FDA $(\mu \mathrm{g} / \mathrm{g} / \mathrm{h})$ in soil samples at eleven sites (Site 13 is represented by Site 11)

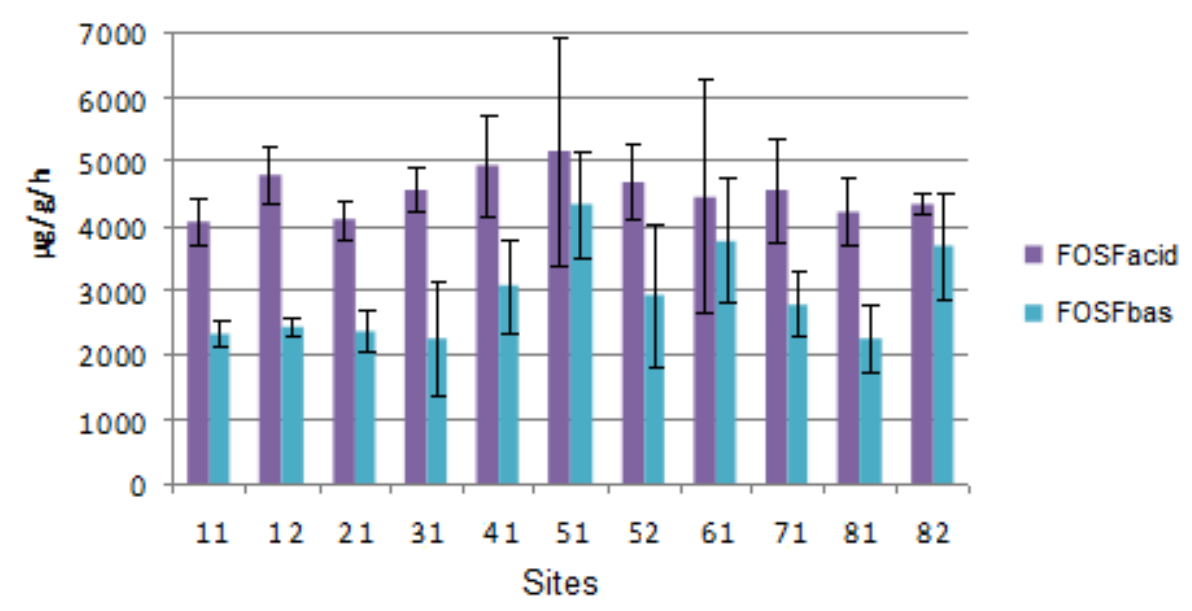

Figure 8. Acid phosphatase activity (FOSFacid) and basic phosphatase (FOSFbas) ( $\mu \mathrm{g} / \mathrm{g} / \mathrm{h})$ in soil samples at eleven sites

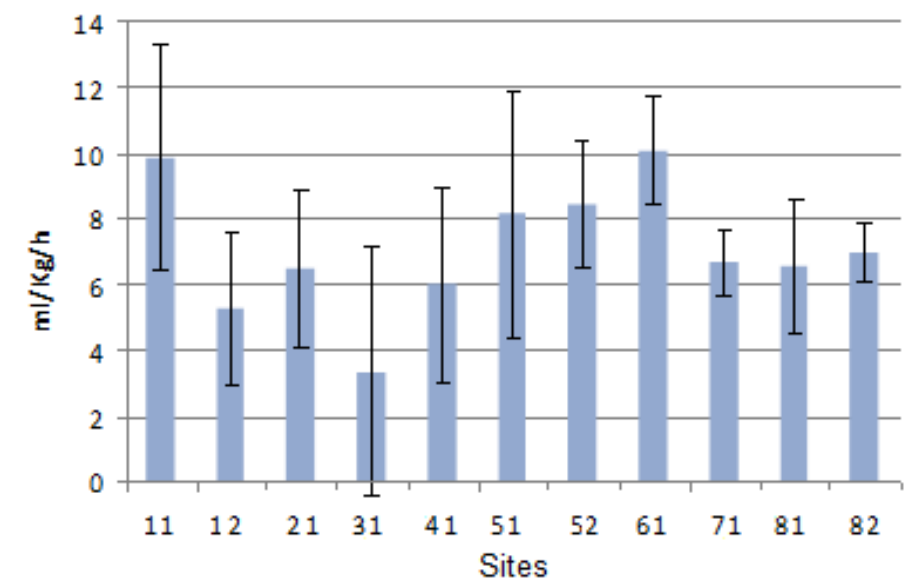

Figure 9. Basal respiration, $\mathrm{CO}_{2}(\mathrm{ml} / \mathrm{kg} / \mathrm{h})$ in soil samples at eleven sites 


\section{Topography and water proximity}

The main water bodies on the Embrapa farm are the Matadouro, Jequitibá, Marinheiro and Papuda streams. The Matadouro stream is at least 600 meters from the nearest sites (in Patches 4, 5, 6 and 7) with an altitude difference between 30 and 50 meters. The Jequitibá stream flows in Patch 8, 150 to 160 meters from the sites, with altitude differences between 7 and 10 meters. The sites of Patch 1 are close to the Papuda stream, between 100 and 200 meters, with altitude differences of 10 meters (Sites 12 and 13) and 30 meters (Site 11), and it is dammed 100 meters upstream from Site 13. In Patch 2, the distance to the Marinheiro stream is 400 meters with an altitude difference of 40 meters. In Patch 3, there is ground water two meters deep and a stream spring downstream. Except for Patches 2, 3 and 6, the others present intermittent drainage.

The parameters related to topography and water proximity (Fig. 10) show that there is a clear difference between Sites 13, 31, 81, 82, which are closer to water and have favorable topographic conditions, and Sites 41, 51, 52, 61 and 71, which are on sloping areas and far from water bodies. An inverse relation is also observed between curvature plane and profile. The sediment accumulation condition is not present simultaneously on both axes for most sites. Very often, one curvature is convex and the other is concave.

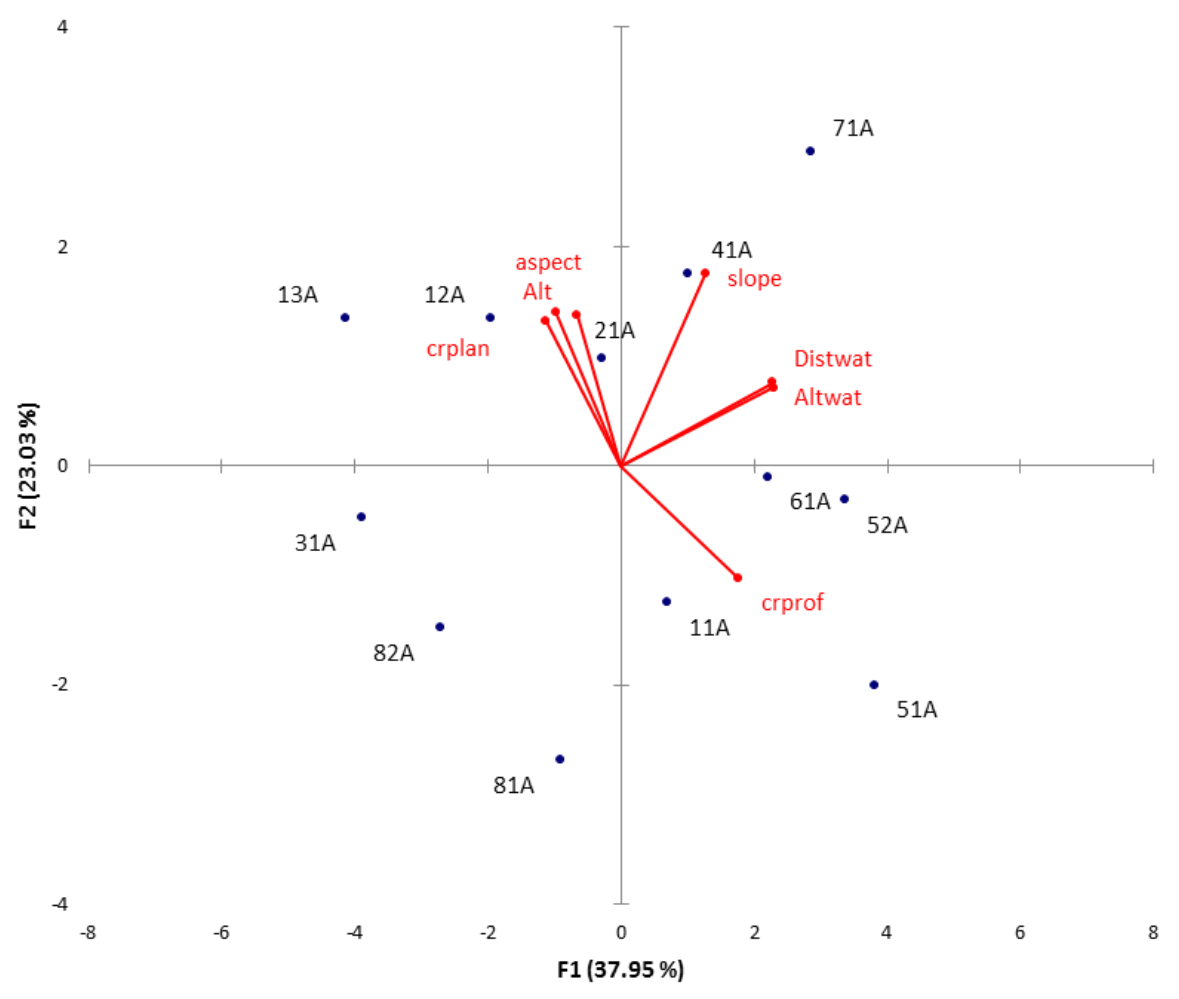

Figure 10. Joint dispersion of topography and water availability parameters and sites for Components 1 and 2 (F1 and F2) of the PCA

\section{Analysis of the patches in the landscape}

The metrics and topography for the forest patches and correlations between variables were strongly represented in the first two components, which concentrate $81.55 \%$ of the total variation (Fig. 11). 
The distribution of the parameters shows that the patches have different factors which are favorable to conservation. Regarding size (Area), the largest patches are 1 and 8, and Patches 4, 5 and 7 have a higher percentage of perimeter bordering natural vegetation (LimAreNat). The last three patches are also more aslope, which is a common feature in the Atlantic Forest landscape, where the remaining natural vegetation is located in areas hard to reach and restricted to human use due to their harsh topographic conditions. The metrics related to shape, CIRCLE and CONTIG did not stand out in any patch. Regarding unfavorable conservation features, we highlight Patch 3 which is the lowest and most isolated.

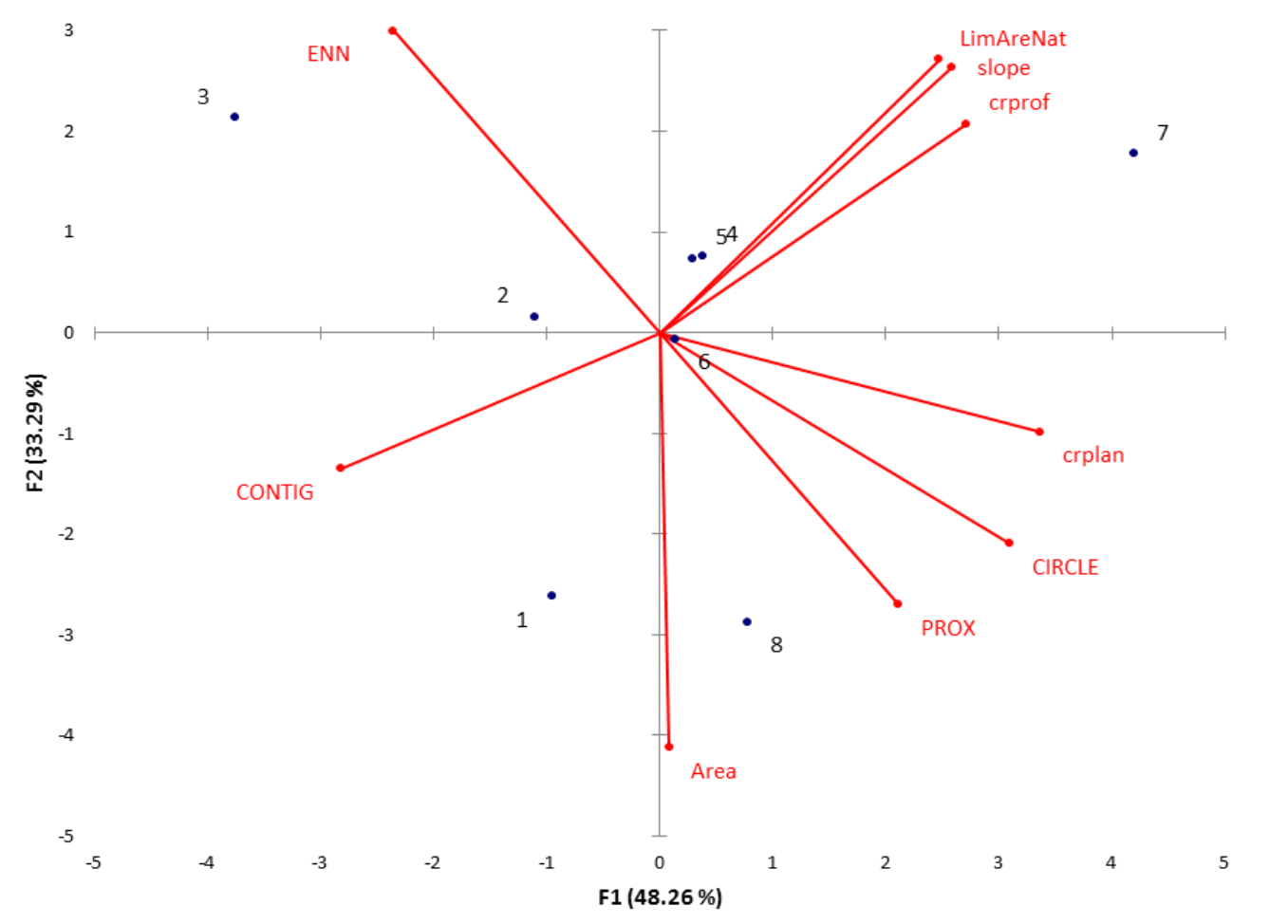

Figure 11. Joint dispersion of topography parameters, landscape metrics and patches for Components 1 and 2 (F1 and F2) of the PCA

\section{Favorable indicators for conservation}

After the PCA analysis, we found that the parameters considered were not enough to explain the current state of conservation of forest patches. Other factors such as water dynamics in soil and subsoil, human interventions, especially fires, wood removal and land use before regeneration may have contributed to the definition of current forest structures and floristic composition. Some of these factors are not available due to the lack of historical record.

However, that does not prevent the use of the selected parameters and their conversion into conservation indicators, as they constitute measurements of the ecosystem. The indicators show the relative degree of conservation of each patch as well as the most favorable or unfavorable factors for conservation. The thresholds for each parameter and their groupings are described in Table 1. 
Table 1. Selected parameters for conservation and ecological stability assessment of Semideciduous Forest patches, with minimum and maximum limits, and its relevance according to goals

\begin{tabular}{|c|c|c|c|c|}
\hline Group & $\begin{array}{l}\text { Original } \\
\text { Variable }\end{array}$ & $\begin{array}{l}\text { Lim. } \\
\text { Min. }\end{array}$ & $\begin{array}{l}\text { Lim. } \\
\text { Max. }\end{array}$ & $\begin{array}{l}\text { Relation to } \\
\text { conservation }\end{array}$ \\
\hline \multirow[t]{6}{*}{ Canopy } & $\operatorname{LAI}\left(\mathrm{m}^{2} \cdot \mathrm{m}^{-2}\right)$ & \multirow{6}{*}{\multicolumn{2}{|c|}{ Data series }} & Linear increase \\
\hline & $\mathrm{h}(\mathrm{m})$ & & & Linear increase \\
\hline & $\mathrm{D}\left(\right.$ Ind. $\left.\mathrm{m}^{-2}\right)$ & & & Linear increase \\
\hline & $\mathrm{B}\left(\mathrm{m}^{2} \cdot \mathrm{ha}^{-1}\right)$ & & & Linear increase \\
\hline & $\mathrm{H}^{\prime}$ & & & Linear increase \\
\hline & $\mathrm{C}$ & & & Linear decrease \\
\hline \multirow[t]{14}{*}{ Soil fertility } & $\mathrm{pH}_{\mathrm{H} 2 \mathrm{O}}$ & $\begin{array}{l}\text { (1) } \mathrm{a}=3 \\
{ }^{(1)} \mathrm{m}=6\end{array}$ & $\begin{array}{l}{ }^{(1)} \mathrm{n}=6,5 \\
{ }^{(1)} \mathrm{b}=9\end{array}$ & Trapezoidal fuzzy \\
\hline & $\begin{array}{l}\mathrm{P}\left(\mathrm{mg} \cdot \mathrm{dm}^{-3}\right) \\
\text { Argila }>60\end{array}$ & 0 & $15^{(2)}$ & $\begin{array}{l}\text { Sites } 11,12,13,2,3,6 \\
\text { Linear increase }\end{array}$ \\
\hline & $\begin{array}{c}\mathrm{P}\left(\mathrm{mg} \cdot \mathrm{dm}^{-3}\right) \\
41<\text { Argila }<60\end{array}$ & 0 & $20^{(2)}$ & $\begin{array}{c}\text { Sites } 4,51,52,7,82 \\
\text { Linear increase }\end{array}$ \\
\hline & $\begin{array}{c}\mathrm{P}\left(\mathrm{mg} \cdot \mathrm{dm}^{-3}\right) \\
21<\text { Argila }<40\end{array}$ & 0 & $30^{(2)}$ & $\begin{array}{l}\text { Linear increase } \\
\text { Site } 81\end{array}$ \\
\hline & $\begin{array}{l}\mathrm{K}\left(\mathrm{mg} \cdot \mathrm{dm}^{-3}\right) \\
\mathrm{CTC}_{\mathrm{T}}>15\end{array}$ & $a=0$ & $\mathrm{~b}=250^{(2)}$ & $\begin{array}{c}\text { Triangular fuzzy } \\
\text { Sites } 11,13,4,7\end{array}$ \\
\hline & $\begin{array}{l}\mathrm{K}\left(\mathrm{mg} \cdot \mathrm{dm}^{-3}\right) \\
5<\mathrm{CTC}_{\mathrm{T}}<15\end{array}$ & 0 & $200^{(2)}$ & $\begin{array}{c}\text { Triangular fuzzy } \\
\text { Sites } 12,2,3,51,52,6,81,82\end{array}$ \\
\hline & $\mathrm{Ca}\left(\mathrm{cmol}_{\mathrm{c}} \mathrm{dm}^{-3}\right)$ & 0 & $10^{(2)}$ & Linear increase \\
\hline & $\mathrm{Mg}\left(\mathrm{cmol}_{\mathrm{c}} \mathrm{dm}^{-3}\right)$ & 0 & $2^{(2)}$ & Linear increase \\
\hline & $\mathrm{H}+\mathrm{Al}\left(\mathrm{cmol}_{\mathrm{c}} \mathrm{dm}^{-3}\right)$ & 0 & $9^{(2)}$ & Linear increase \\
\hline & $\mathrm{V} \%(\mathrm{~V})$ & 0 & 100 & Linear increase \\
\hline & $\mathrm{m} \%(\mathrm{~m})$ & 0 & 100 & Linear decrease \\
\hline & M.O. (dag.kg ${ }^{-1}$ ) & 0 & $15^{(2)}$ & Linear increase \\
\hline & $\mathrm{Cu}\left(\mathrm{mg} \cdot \mathrm{dm}^{-3}\right)$ & 0 & $2^{(2)}$ & Linear increase \\
\hline & $\begin{array}{l}\text { Profundity H. A } \\
\text { (prof) }(\mathrm{cm})\end{array}$ & Dat: & series & Linear increase \\
\hline \multirow{2}{*}{$\begin{array}{l}\text { Nutrient } \\
\text { cycling }\end{array}$} & Leaves $\left(\mathrm{g} \cdot \mathrm{m}^{2}\right.$ year $\left.^{-1}\right)$ & 100 & 900 & Linear increase \\
\hline & $\begin{array}{l}\text { Decomposition rate } \\
(\mathrm{K})\end{array}$ & 0 & -0.007 & Linear decrease \\
\hline \multirow{3}{*}{ Topography } & $\begin{array}{l}\text { Curvature plane } \\
\text { (crplan) }\end{array}$ & $-0.6^{(3)}$ & $0.6^{(4)}$ & Linear decrease \\
\hline & $\begin{array}{l}\text { Curvature profile } \\
\text { (crprof) }\end{array}$ & $-0.6^{(3)}$ & $0.6^{(4)}$ & Linear decrease \\
\hline & Slope $\left({ }^{\circ}\right)$ & 0 & 25 & Linear decrease \\
\hline \multirow[b]{2}{*}{$\begin{array}{l}\text { Water } \\
\text { proximity }\end{array}$} & $\begin{array}{l}\text { Distance of water } \\
\text { resources (distwat) } \\
(\mathrm{m})\end{array}$ & \multicolumn{2}{|c|}{ Data series } & Linear decrease \\
\hline & $\begin{array}{l}\text { Altitude difference in } \\
\text { relation to water } \\
\text { resources (altwat) (m) }\end{array}$ & \multicolumn{2}{|c|}{ Data series } & Linear decrease \\
\hline \multirow{3}{*}{$\begin{array}{l}\text { Patches in the } \\
\text { landscape }\end{array}$} & Area (ha) & \multicolumn{2}{|c|}{ Data series } & Linear increase \\
\hline & CIRCLE & 0 & 1 & Linear decrease \\
\hline & CONTIG & 0 & 1 & Linear increase \\
\hline
\end{tabular}




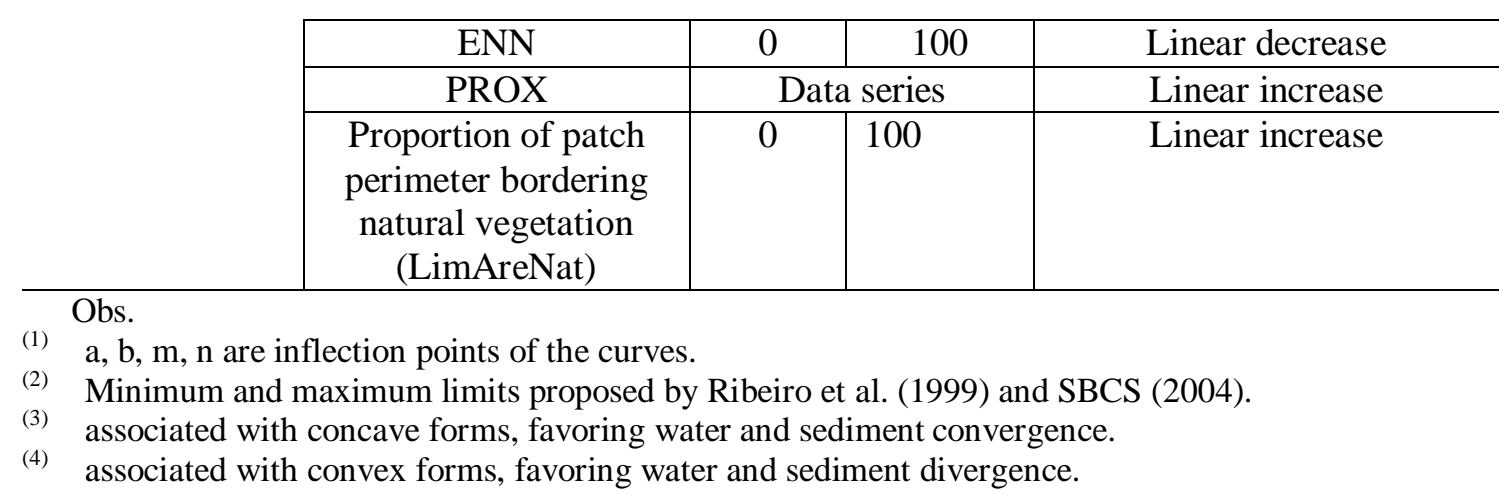

After selecting the parameters, indicators were calculated for each group. For the canopy group, the canopy conservation indicator (canopy ind.) is presented in Table 2. The proximity of values of some sites groups them in a similar way to the distribution observed in Figure 2. For example, 81 and 82 with best canopy quality and Sites 11, 12, $13,61,71$ with lower canopy quality.

Table 2. Standardized canopy parameters (0-1) and canopy conservation indicator (canopy ind. ) per site. Lower values close to zero indicate unfavorable for conservation and values close to 1, favorable for conservation

\begin{tabular}{rrrrrrrr}
\hline Site & LAI & $\mathrm{h}$ & $\mathrm{D}$ & $\mathrm{B}$ & $\mathrm{H}^{\prime}$ & $\mathrm{C}$ & canopy ind. \\
\hline 11 & 0.12 & 0.05 & 0.32 & 0.21 & 0.42 & 0.57 & 0.28 \\
12 & 0.26 & 0.3 & 0.2 & 0 & 0.34 & 0.55 & 0.28 \\
13 & 0.17 & 0 & 0.7 & 0.07 & 0 & 0.00 & 0.16 \\
21 & 0.12 & 0.39 & 0.63 & 0.66 & 0.71 & 0.75 & 0.54 \\
31 & 1 & 0.34 & 0.51 & 0.7 & 0.69 & 0.75 & 0.67 \\
41 & 0.7 & 0.3 & 0.76 & 0.53 & 0.66 & 0.64 & 0.60 \\
51 & 0.4 & 0.73 & 0.22 & 0.68 & 0.73 & 0.91 & 0.61 \\
52 & 0.69 & 0.54 & 0.52 & 0.72 & 0.51 & 0.63 & 0.60 \\
61 & 0.35 & 0.65 & 0.21 & 0.37 & 0.57 & 0.71 & 0.48 \\
71 & 0 & 0.62 & 0 & 0.22 & 0.3 & 0.67 & 0.30 \\
81 & 0.75 & 0.22 & 1 & 1 & 0.95 & 0.90 & 0.80 \\
82 & 0.8 & 1 & 0.56 & 0.88 & 1 & 1.00 & 0.87 \\
\hline
\end{tabular}

In order to calculate the soil fertility indicator (Soil ind.), we disregarded parameters $\mathrm{Fe}, \mathrm{Zn}$ and $\mathrm{Mn}$ due to their high levels in the soil, and because there are no references to toxic levels for trees. Texture parameters were not considered because only Horizon A was studied and the parameters were unexpressive. The fertility indicator (Table 3) did not follow the same trend as the canopy indicator. Site 31 was in Typic Haplustox (soil with low base saturation and low fertility), but that soil sustained vegetation with good canopy and diversity, helped by the existence of groundwater 2 meters below it. On the contrary, Sites 41 and 51, with good fertility indicators, were among the most affected by drought, the distance from water bodies and their topographical position, with intermediate values of canopy indicators.

It is important that even the lower soil fertility indicators still had reasonable fertility levels in Horizon A supplied by nutrient cycling. 
Table 3. Soil fertility parameters of Horizon A selected and standardized (0-1) and soil fertility indicator (Soil ind.) per site. Result of Site 11 also represents Site 13

\begin{tabular}{ccccccccccccc}
\hline Site & $\mathrm{P}$ & $\mathrm{K}$ & $\mathrm{Ca}$ & $\mathrm{Mg}$ & $\mathrm{H}+\mathrm{Al}$ & $\mathrm{M} . \mathrm{O}$. & $\mathrm{Cu}$ & Prof & $\mathrm{pH}_{\mathrm{H} 2 \mathrm{O}}$ & $\mathrm{V}$ & $\mathrm{m}$ & Soil ind. \\
\hline 11 & 0.35 & 0.42 & 0.91 & 0.41 & 0.50 & 0.62 & 0.13 & 0.47 & 0.86 & 0.62 & 1.00 & 0.57 \\
12 & 0.40 & 0.49 & 0.41 & 0.41 & 0.42 & 0.41 & 0.19 & 0.77 & 0.86 & 0.39 & 0.86 & 0.52 \\
13 & 0.35 & 0.42 & 0.91 & 0.41 & 0.50 & 0.62 & 0.13 & 0.47 & 0.86 & 0.62 & 1.00 & 0.57 \\
21 & 0.22 & 0.31 & 0.09 & 0.09 & 0.28 & 0.30 & 0.45 & 0.67 & 0.74 & 0.12 & 0.46 & 0.39 \\
31 & 0.58 & 0.22 & 0.59 & 0.20 & 0.50 & 0.43 & 0.35 & 0.00 & 0.85 & 0.52 & 1.00 & 0.48 \\
41 & 0.67 & 1.00 & 0.66 & 0.86 & 0.42 & 0.82 & 0.40 & 0.47 & 0.98 & 0.56 & 1.00 & 0.70 \\
51 & 0.26 & 0.41 & 0.64 & 0.72 & 0.43 & 0.59 & 0.49 & 0.85 & 0.88 & 0.50 & 0.84 & 0.58 \\
52 & 0.20 & 0.67 & 0.63 & 0.89 & 0.55 & 0.64 & 0.86 & 0.17 & 1.00 & 0.61 & 1.00 & 0.60 \\
61 & 0.31 & 0.43 & 0.29 & 0.17 & 0.05 & 0.59 & 0.12 & 1.00 & 0.69 & 0.19 & 0.41 & 0.43 \\
71 & 0.53 & 0.81 & 0.82 & 0.63 & 0.54 & 0.50 & 0.31 & 0.09 & 0.89 & 0.64 & 0.99 & 0.59 \\
81 & 0.18 & 0.56 & 0.14 & 0.34 & 0.29 & 0.37 & 0.42 & 0.61 & 0.63 & 0.20 & 0.53 & 0.41 \\
82 & 0.36 & 1.00 & 0.82 & 0.81 & 0.90 & 0.41 & 0.74 & 0.82 & 0.74 & 0.89 & 1.00 & 0.74 \\
\hline
\end{tabular}

The nutrient cycling indicator (Cycl ind.) (Table 4) showed that the response to cycling was similar at most sites, having its lowest limit observed at Site 12, and its highest limit at Site 31.

Table 4. Parameters of cycling selected and standardized (0-1) and the nutrients cycling indicator (Cycl ind.) per site

\begin{tabular}{|c|c|c|c|}
\hline Site & leaves & $\mathrm{k}$ & Cycl ind. \\
\hline 11 & 0.30 & 0.72 & 0.51 \\
\hline 12 & 0.19 & 0.44 & 0.32 \\
\hline 13 & 0.30 & 0.72 & 0.51 \\
\hline 21 & 0.33 & 0.55 & 0.44 \\
\hline 31 & 0.77 & 0.69 & 0.73 \\
\hline 41 & 0.37 & 0.42 & 0.39 \\
\hline 51 & 0.45 & 0.54 & 0.49 \\
\hline 52 & 0.30 & 0.38 & 0.34 \\
\hline 61 & 0.35 & 0.44 & 0.39 \\
\hline 71 & 0.18 & 0.57 & 0.37 \\
\hline 81 & 0.46 & 0.67 & 0.57 \\
\hline 82 & 0.54 & 0.60 & 0.57 \\
\hline
\end{tabular}

The topography indicator (Topo ind.) (Table 5) displayed no major differences between the sites. An exception occurred at Site 71, where unfavorable canopy parameters also were found. In that case, the low topography indicator may have contributed to the poor forest development at the site.

The water proximity indicator (Wat ind.) (Table 5) shows that Sites 21, 41, 51, 61 are less likely to have underground water supply, even though their ICds showed intermediate values. Sites of Patches 1 and 8 presented close Wat ind. values, although their responses, in terms of ICd, were very different, which shows that the proximity to an isolated water resource cannot respond to the level of forest conservation. 
Table 5. Standardized parameters of topography and water proximity (0-1) and topography (Topo ind.) and water proximity (ICwat) indicators per site

\begin{tabular}{cccccccc}
\hline Site & crprof & crplan & slope & Topo ind. & distwat & altwat & Wat ind. \\
\hline 11 & 0.36 & 0.52 & 0.70 & 0.53 & 0.75 & 0.26 & 0.51 \\
12 & 0.64 & 0.51 & 0.35 & 0.50 & 0.75 & 0.79 & 0.77 \\
13 & 0.76 & 0.41 & 0.74 & 0.64 & 0.75 & 0.79 & 0.77 \\
21 & 0.69 & 0.37 & 0.71 & 0.59 & 0.33 & 0.00 & 0.17 \\
31 & 0.71 & 0.25 & 0.73 & 0.56 & 1.00 & 1.00 & 1.00 \\
41 & 0.64 & 0.41 & 0.54 & 0.53 & 0.00 & 0.00 & 0.00 \\
51 & 0.36 & 0.74 & 0.68 & 0.59 & 0.00 & 0.00 & 0.00 \\
52 & 0.55 & 0.92 & 0.42 & 0.63 & 0.00 & 0.00 & 0.00 \\
61 & 0.55 & 0.52 & 0.61 & 0.56 & 0.00 & 0.00 & 0.00 \\
71 & 0.42 & 0.07 & 0.11 & 0.20 & 0.00 & 0.00 & 0.00 \\
81 & 0.52 & 0.53 & 0.76 & 0.60 & 0.75 & 0.84 & 0.80 \\
82 & 0.53 & 0.48 & 0.90 & 0.64 & 0.75 & 0.84 & 0.80 \\
\hline
\end{tabular}

The landscape indicator (Landsc ind.) was obtained from the selected parameters related to patches (Table 6). The highest value was that of Patch 8 , due to its size and proximity to other patches, although its border with natural areas is not relatively high: $49 \%$. The low value for this metric also shows the risk of harmful interference in forest conservation. In the case of the study area, livestock from a surrounding pasture area often escapes causing damage to patch regeneration. Patch 7, a smaller area, has a large border with natural areas, 90\%, indicating that the change from Semideciduous Forest to Savannah Woodland, Grassy-Woody Savannah, may be a result of soil and topographical conditions -- in other words, natural constraints.

Table 6. Standardized parameters and landscape indicator (Landsc ind.) per patch

\begin{tabular}{cccccccc}
\hline Frag. & Area & CIRCLE & CONTIG & ENN & PROX & LimAreNat & Landsc ind. \\
\hline 1 & 1.00 & 0.26 & 0.98 & 1.00 & 0.44 & 0.24 & 0.65 \\
2 & 0.12 & 0.35 & 0.98 & 0.63 & 0.41 & 0.58 & 0.51 \\
3 & 0.00 & 0.61 & 0.98 & 0.00 & 0.00 & 0.44 & 0.34 \\
4 & 0.28 & 0.21 & 0.98 & 0.67 & 0.08 & 0.84 & 0.51 \\
5 & 0.21 & 0.36 & 0.98 & 0.85 & 0.18 & 0.70 & 0.55 \\
6 & 0.09 & 0.28 & 0.98 & 0.85 & 0.50 & 0.58 & 0.55 \\
7 & 0.08 & 0.14 & 0.97 & 0.82 & 0.68 & 0.90 & 0.60 \\
8 & 0.92 & 0.14 & 0.98 & 0.98 & 1.00 & 0.49 & 0.75 \\
\hline
\end{tabular}

When considering the joint analysis of indicators (Fig. 12), we can assess their contribution, identifying weaknesses and strengths. Knowledge on the factors limiting conservation allows selecting the most appropriate measures to mitigate degradation and promote conservation of forest patches. 


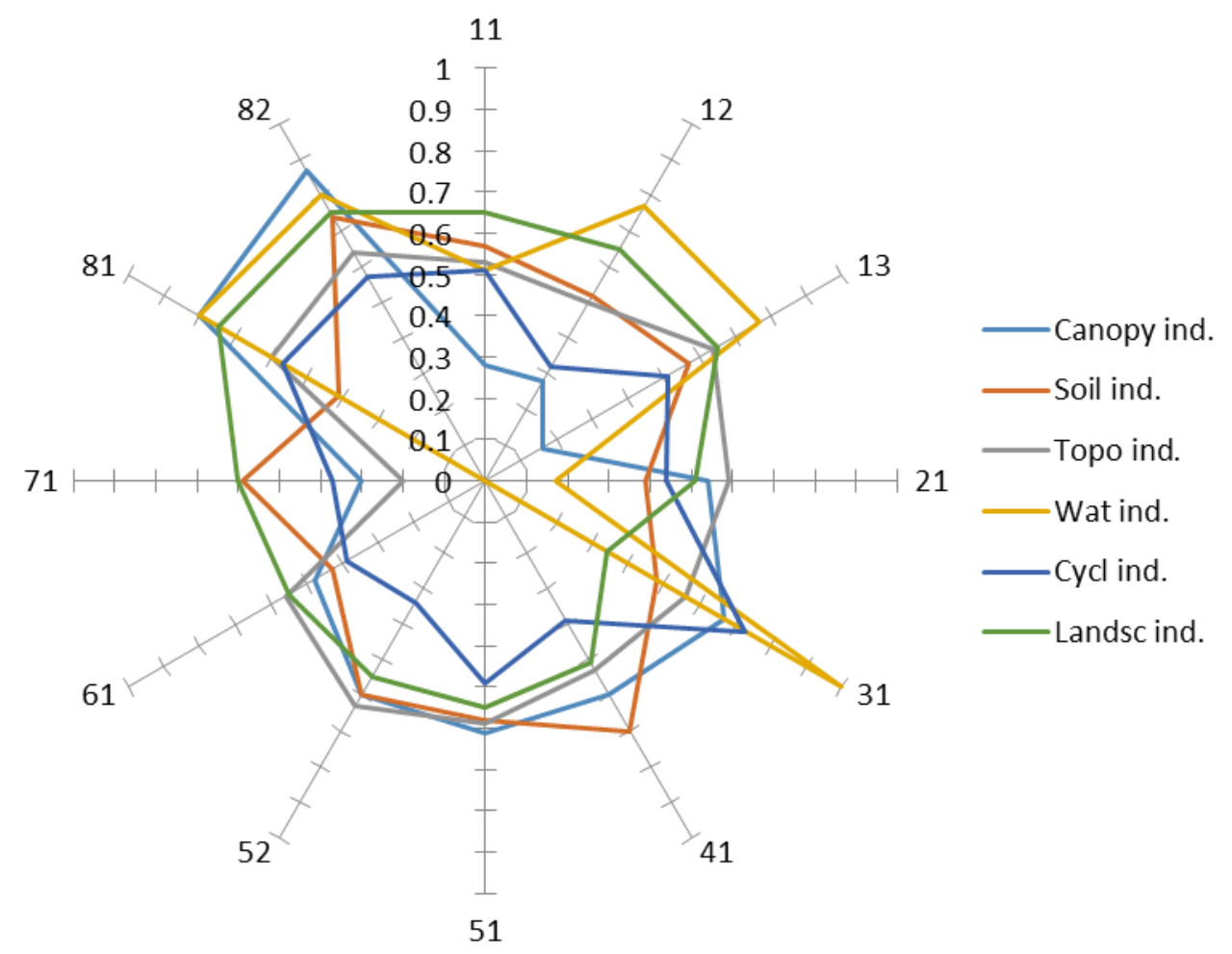

Figure 12. Favorable indicators for conservation at each site

Concerning the canopy indicator, the lowest values were observed on Sites 11, 12, 13 and 71. With the exception of Site 71, which had great topographic limitations, the others had been pasture areas regenerating for the last 50 years. Sites 21 and 61 combined low values for the canopy, fertility and access to groundwater indicators. At Site 41 , there is evidence that favorable fertility combined with unfavorable water conditions accounted for the moderate canopy indicator.

Site 82 coupled the best canopy indicator with good results for the other indicators, showing the positive effect of the set of indicators for conservation. Sites 51 and 52 had intermediate values for most indicators, including canopy.

The nutrient cycling indicator presented a tendency towards lower values in sites with higher slope parameters. Its best performance was at Site 31, which also performed well for the water proximity and canopy indicators.

We observe that the lowest value for landscape indicator was obtained at Patch 3, contributing to its small size and isolation in the landscape. Its high conservation indicator associated with canopy was probably due to the moisture caused by the 2meter-deep groundwater and a likely recent isolation. This result shows that although this patch presented good conditions, it is at risk due to the edge effect, reduction of some fauna groups and barriers to gene flow.

Patch 1 had low conservation values for the proximity and percentage of border with natural areas parameters. However, the integrated result of the landscape indicator was satisfactory due to the positive influence of the area parameter.

Patch 8 had the best attributes on the site and landscape scales, showing favorable characteristics for conservation. In this case, the maintenance of these characteristics requires actions to prevent degradation by hunting, cattle invasion and fires. 
The edaphic, water, topography and landscape qualities are not the only qualities affecting the structure and diversity of the patch, but also the age and history of human interventions such as logging and, especially, fire.

The age of the patches is unknown. Using aerial photographs from 1964 (photography n. 11591 / VM AST - 10 1370PMW R-82 of 09.02.1964) we observed that the remaining patches at that time were 2, 3, 4, 5, 7 and 8. Patch 6 was partially covered and Patch 1 was fully covered by pasture or other agricultural activity.

The farm has belonged to Embrapa Milho e Sorgo since 1976 and was formed by cotton test fields, corn fields for breeding and pastures at different times, as well as the acquisition of neighboring lands (Embrapa Milho e Sorgo, 2000). Therefore, we estimated that parts of Patches 1 and 6 are between 40 and 50 years old.

There are no historical records of anthropogenic interference in the natural environment. The reports are inaccurate, making it impossible to measure their influence on vegetation. All patches had traces of fire, some had small fragments of charcoal, bark or pieces of charred trunks in their first layers of soil, showing that fire has occurred at different times, but its intensity and scope could not be measured. The last fire was in September 2012 in Patches 1 and 2, causing burning of litter, the base of some trees, lianas and dead trees, reaching the treetops. That fire induced strong leaf fall because of stress. At the end of the rainy season, in March 2013, few traces of fire were visible.

Although the effects of human impacts and environmental conditions could not be isolated to know their influence on the current conservation status, the analysis showed some factors which contributed to the conservation of the patches. For example, favorable canopy parameters with unfavorable edaphic quality at Site 31 indicated the importance of considering a third factor, in this case, water proximity as a parameter related to groundwater supply.

The purpose of this study is not to clarify all the complex interactions between environmental components, which would require a long-term multidisciplinary survey and a control of all ecosystem dynamics phenomena. Our proposal is the relative evaluation of patch conservation by using groups of parameters, which indicate strengths and weaknesses for decision making regarding their conservation.

\section{Conclusion}

The methodology for the assessment of forest conservation in fragmented landscapes allowed gathering information on factors that express their weaknesses and strengths.

The results obtained from the application of the method did not express exactly the current conditions of the patches and sites studied in some cases. The limitations are inherent to natural conditions, lack of record of human activities in the area and restriction of sampling considering the diversity of the environmental conditions.

In the overall assessment, the applied method and the achieved results reached the proposed goal as its application allowed the identification of patches in better and worse condition, and provided information on the factors that contribute to this status. This knowledge can help guide and select the most appropriate measures to mitigate degradation and identify forest conservation strategies. 
Acknowledgements. This study is a result of project sponsored by CNPq 561864/2010-1 "Parameters of forest fragmentation as subsidy for the environment quality and recovery of degraded environments", with the support of FAPEMIG to trainee fellowships. We thank Sâmara E. F. Carvalho and Marcos Chamon, the team that participated in the data gathering and made the monitoring possible, Andréa Fonseca Silva and Morgana Flávia Rodrigues Rabelo, botanists at Epamig Herbarium who identified tree species, Douglas Paula Soares, Felipe Silva Guimarães and Dauler Perona Gomes, who helped in the installation and measurements of forest inventory.

\section{REFERENCES}

[1] A.P.G.[=Angiosperm Phylogeny Group] III (2009): “An update of the Angiosperm Phylogeny Group classification for the orders and families of flowering plants: APG III", Botanical Journal of the Linnean Society, vol. 161, pp. 105-121.

[2] Adam, G., Duncan, H. (2001): Development a sensitive and rapid method for the measurement of total microbial for the measurement of total microbial activity using fluorescein diacetate (FDA) in a range of soils. - Soil Biology and Biochemistry 33: 943951.

[3] Alef, K., Keiner, D. (1986): Arginine ammonification,a simple method to estimate microbial activity potentials in soils. - Soil Biol. Biochem., 18( 2):233-235.

[4] Altieri, M.A. (1999): The ecological role of biodiversity in agroecosystems. - Agriculture, Ecosystems and Environment 74: 19-31.

[5] Aquino, A. M., Assis, L. R. (2005): Processos biológicos no sistema solo-planta: ferramentas para uma agricultura sustentável. Embrapa Agrobiologia. - Brasília, DF: Embrapa Informação Tecnológica.

[6] Araujo, E.L., Ferraz, E.M.N. (2003): Processos ecológicos mantenedores da diversidade vegetal na caatinga: estado atual do conhecimento. - In: Claudino-Sales, V. (ed.). Ecossistemas brasileiros: manejo e conservação. Fortaleza, Expressão Gráfica e Editora, p. 115-128.

[7] Barichello, L. R.; Schumacher, M. V.; Vogel, H. L. M.; Dallago, J. S. (2000): Quantificação dos nutrientes no solo e serapilheira de diferentes estágios sucessionais em um sistema de agricultura migratória. - In: Reunião Sul Brasileira de Ciência do Solo, 3. , 2000, Pelotas. Resumos expandidos... Pelotas, 1 CD-ROM.

[8] Brun, E. J., Schumacher, M. V., Vaccaro, S. (1999): Produção de serapilheira e devolução de nutrientes em três fases sucessionais de uma Floresta Estacional Decidual no município de Santa Tereza (RS). - In: Simpósio de fertilização e nutrição florestal, 1., 1999, Piracicaba. Anais... Piracicaba: ESALQ, p.348-364.

[9] Costa, T.C.C., Accioly, L.J.O., Oliveira, L.M.T., Oliveira, M.A.J., Guimarães, D.P. (2009b): Interação de fatores biofísicos e antrópicos com a diversidade florística na indicação de áreas para conservação do bioma Caatinga. - Sociedade \& Natureza, Uberlândia 21 (1): 19-37.

[10] Costa, T.C.C., Oliveira, M.A.J., Accioly, L.J.O., Silva, F. H. B. B. da (2009a): Análise da degradação da caatinga no núcleo de desertificação do Seridó (RN/PB). - Rev. Bras. Eng. Agríc. Ambient. 13 (Suplemento):961-974.

[11] Costa, T.C.C., Viana, J.H.M., Ribeiro, J.L. (2014): Semideciduous Seasonal Forest Production of Leaves and Deciduousness in Function of the Water Balance, LAI, and NDVI. - International Journal of Ecology. V. 2014, 15 pages http://dx.doi.org/10.1155/2014/923027

[12] Cunha, G. C. (1997): Aspectos da ciclagem de nutrientes em diferentes fases sucessionais de uma floresta estacional do Rio Grande do Sul. (86 pp.) Dissertação (Mestrado em Engenharia Florestal). - Escola Superior de Agricultura "Luiz de Queiroz", Piracicaba. 
[13] Donagema, G. K. (2011): Manual de métodos de análise de solos / organizadores, Guilherme Kangussú Donagema. [et al.]. - Dados eletrônicos. - Rio de Janeiro: Embrapa Solos, 230 p. - (Documentos / Embrapa Solos, ISSN 1517-2627; 132)

[14] Eastman, J. R., Jin, W., Kyem, P. A. K., Toledano, J. (1995): Raster procedures for multicriteria, multi-objetive decisions. - Photogrammetric Engineering and Remote Sensing, Bethesda 61(5): 539-547.

[15] Embrapa Milho e Sorgo (2000): Novas trilhas no sertão - história da pesquisa agropecuária em Sete Lagoas: das origens à Embrapa - Sete Lagoas,. 184 p. ISBN 858580-203-0.

[16] Feger, K. H., Raspe, S. (1998). Ökosystemforschung im chwarzwald: Auswirkungen von atmogenen einträgen und Restabilisierungsmassnahmen auf den Wasser- und Stoffhaushalt von Fichtenwäldern. - In: Raspe, Feger und Zotil (Hrsg). Verbundprojekt Arinus. Landsberg: Umweltforschung in Baden-Württenberg, p.1-18.

[17] Gomide, R. L., Albuquerque, P.E.P., Andrade, C.L.T., Durães, F.O.M., Viana, J.H.M. (2006): Caracterização climática e determinação da necessidade hídrica de culturas do sítio - específico de precisão de Sete Lagoas para fenotipagem de genótipos de cereais tolerantes a seca. Sete Lagoas, MG, 7p. Acesso em: 30 de out. 2014. Online. Disponível em: http://www.alice.cnptia.embrapa.br/handle/doc/490096.

[18] Hayashi, S.N. (2006): Dinâmica de serapilheira em uma cronossequência de florestas no Município de Capitão Poço - PA. Belém. Mestrado em Botânica Tropical. UFRAM/Museu Emílio Goeldi. 61p.

[19] IBGE. 2012. Manual técnico da vegetação brasileira: sistema fitogeográfico, inventário das formações florestais e campestres, técnicas e manejo de coleções botânicas, procedimentos para mapeamentos. $2^{\mathrm{a}}$ Ed. IBGE-Instituto Brasileiro de Geografia e Estatística, Rio de Janeiro, 2012, 275p.

[20] IBGE. (1988): Mapa de vegetação do Brasil, SEPLAN/PR.

[21] Kandeler, E.; Gerber, H. (1988): Short term assay of soil urease activity using colorimetric determination ammonium. - Biol.Fertil. Soils 6:68-72.

[22] Kandziora, M.; Burkhard, B.; Muller, F. (2013): Interactions of ecosystem properties, ecosystem integrity and ecosystem service indicators: a theoretical matrix exercise. Ecological Indicators 28: 54-78.

[23] Li-Cor. Lai-2200 (2011): Plant Canopy Analyzer. Instruction Manual. Li-Cor Biosciences, 2009. 3rd printing: May 2011.

[24] Machado, I.C.; Lopes, A.V. (2002): A polinização em ecossistemas de Pernambuco: uma revisão do estado atual do conhecimento. - In: M. Tabarelli; J.M.C. Silva (orgs.). Diagnóstico da Biodiversidade de Pernambuco. Recife: Secretaria de Ciência, Tecnologia e Meio-Ambiente, Fundação Joaquim Nabuco e Editora Massangana. p. 583-596.

[25] Manzoni, S.; Piñeiro, G.; Jackson, R.B.; Jobbágy, E.G.; Kim, J.H.; Porporato, A. (2012): Analytical models of soil and litter decomposition: Solutions for mass loss and timedependent decay rates. - Soil Biology \& Biochemistry 50: 66-76.

[26] Marriel, I.E.; Adelario, M.S.; Borges, A.L.; Oliveira, A.A.N.; Silva, U.C.; Guimarães, L.J.M. (2008): Variação da Atividade de Arginase e Urease na Rizosfera de Genótipos de Milho Contrastantes no Uso de Nitrogênio. - In: CONGRESSO NACIONAL DE MILHO E SORGO, 27.; SIMPOSIO BRASILEIRO SOBRE A LAGARTA-DO-CARTUCHO, SPODOPTERA FRUGIPERDA, 3.; WORKSHOP SOBRE MANEJO E ETIOLOGIA DA MANCHA BRANCA DO MILHO, Londrina. Agroenergia, produção de alimentos e mudanças climáticas: desafios para milho e sorgo: trabalhos e palestras. [Londrina]: IAPAR; [Sete Lagoas]: Embrapa Milho e Sorgo, No. 20814.

[27] Mcgarigal, K. Fragstats: user guideline, version 3. Disponível em: <http://www.umass.edu/landeco/research/fragstats/documents/User\%20guidelines/User\% 20guidelines\%20content.htm>. Accessed on:09 Sept. 2011. 
[28] Melo Filho, J. F.; Souza, A. L. V.; Souza, L. S. (2007): Determinação do índice de qualidade subsuperficial em um latossolo amarelo coeso dos tabuleiros costeiros, sob floresta natural. - R. Bras. Ci. Solo 31: 1599-1608.

[29] Moreira, F.M.S.; Siqueira, J.O. (2002). Microbiologia e bioquímica do solo. Lavras: UFLA, 625pp.

[30] Nascimento, H. E. M., Laurance, W. F. (2006): Efeitos de área e de borda sobre a estrutura florestal em fragmentos de floresta de terra-firme após 13-17 anos de isolamento. - Acta Amazônica 36(2): 183 - 192.

[31] Noss, R. F. (1999). Assessing and monitoring forest biodiversity: a suggested framework and indicators. - Forest Ecology and Management 15: 135-146.

[32] Oliveira, L. M. T., França, G. B., Nicácio, R. M., Antunes, M. A. H., Costa, T. C. C., Torres, A. R., França, J. R. A. (2010): A study of the El Niño-Southern Oscillation influence on vegetation indices in Brazil using time series analysis from 1995 to 1999. International Journal of Remote Sensing 31 (2), DOI:10.1080/01431160902893477

[33] Paula, S. A.; Lemos Filho, J.P. (2001): Dinâmica do dossel em mata semidecídua no perímetro urbano de Belo Horizonte, MG. - Revista Brasileira de Botânica, São Paulo 24 (4) (suplemento): 545-551.

[34] Poggiani, F.; Schumacher, M.V. (2000): Ciclagem de nutrientes em florestas nativas. - In: Gonçalves, J.L.M.; Benedetti, V. (eds.) Nutrição e fertilização florestal. Piracicaba: Instituto de Pesquisas Florestais. p.287-308.

[35] Ribeiro, A.C.; Guimaraes, P.T.G.; Alvarez, V.H. (eds.) (1999): Recomendação para o uso de corretivos e fertilizantes em Minas Gerais: 5a. aproximação. - Comissão de Fertilidade do Solo do Estado de Minas Gerais, Viçosa:, 359p. (Titulo da capa: Recomendações para o uso...Biblioteca(s): Embrapa Amazônia Ocidental; Embrapa Arroz e Feijão; Embrapa Cerrados; Embrapa Hortaliças; Embrapa Milho e Sorgo; Embrapa Semiárido.)

[36] Oliveira, N.B.; McDougall, C.; Ritchie, B.; Hartanto, H.; Haggith, M.; Setyawati, T.(2000): Developing criteria and indicators of community managed forests as assessment and learning tools: objectives, methodologies and results. - CIFOR, 303p. https://books.google.com.br/books?id=rsyZM1To59YC.

[37] Sampaio, E.V.S.B. (2003): Caracterização da caatinga e fatores ambientais que afetam a ecologia das plantas lenhosas. p. 129-142. - In: V.C. Sales (ed.). Ecossistemas brasileiros: manejo e conservação. Fortaleza, Expressão Gráfica e Editora.

[38] SBCS (2004): Manual de adubação e de calagem para os Estados do Rio Grande do Sul e de Santa Catarina. Comissão de Química e Fertilidade do Solo. 10 ed. Porto Alegre, 400p.il.

[39] Sih, A., Jonsson, B. G., Luikart, G. (2000): Habitat loss: ecological, evolutionary and genetic consequences. - Trends in Ecology and Evolution 15:132-134.

[40] Silva, C.J., Lobo, F.A., Bleich, M.E., Sanches, L. (2009): Contribuição de folhas na formação da serrapilheira e no retorno de nutrientes em floresta de transição no norte de Mato Grosso. - Acta Amazonica 39 (3): 591-600.

[41] Silva, E.E., Azevedo, P. H. S., De-Polli, H. (2007): Determinação da respiração basal (RBS) e quociente metabólico do solo $\left(\mathrm{qCO}_{2}\right)$. - Comunicado Técnico 99, Seropédica/RJ.

[42] Silveira, A. P. D., Freitas, S. S. (2007): Microbiota do solo e qualidade ambiental. Campinas: Instituto Agronômico, $312 \mathrm{p}$.

[43] Singh, R.K., Murty, H.R., Gupta, S.K., Dikshit, A.K. (2009): An overview of sustainability assessment methodologies. - Ecological Indicators 9: 189-212.

[44] Tabarelli, M., Lopes, A.V., Peres, C.A. (2008): Edge-effects drive Tropical Forest fragments towards an early-successional system. - Biotropica 40: 657-661.

[45] Tabatai, M.A., Bremmer, J.M. (1969): Use of pNitrophenyl phosphate for assay of soil phosphatase activity. - Soil Biology and Biochemistry 1: 301-307.

[46] Turner, M. G. (1989): Landscape ecology: The effect of pattern on process. - Annu. Rev. Ecol. Syst. 20:171 - 197. 
[47] USDA (1999). Soil Survey Staff. Soil Taxononmy - a basic system of soil classification for making and interpreting soil survey. 2 ed., Washington, $871 \mathrm{p}$.

[48] USDA (2003). Base Indicators of Forest Sustainability: Metrics and Data Sources for State and Regional Monitoring. Forest Service Northeastern Area State and Private Forestry and Northeastern Forest Resource Planners Association In cooperation with: Northeastern Area Association of State Foresters, Washington, 70p.

[49] Valenti, M.W., Cianciaruso, M.V., Batalha, M.A. (2008): Seasonality of litterfall and leaf decomposition in a Cerrado site. - Brazilian Journal Biology 68 (3): 459-465.

[50] Werneck, M. S.; Pedralli, G.; Gieseke, L. F. (2001): Produção de serrapilheira em três trechos de uma floresta semidecidual com diferentes graus de perturbação na Estação Ecológica de Tripuí, Ouro Preto, MG. - Revista Brasileira de Botânica. 24:195-198.

[51] Zhang, W., Swinton, S.M. (2009): Incorporating natural enemies in an economic threshold for dynamically optimal pest management. - Ecological Modelling 220: 13151324. 